\title{
InSAR-based characterization of rock glacier movement in the Uinta Mountains, Utah, USA
}

\author{
George Brencher ${ }^{1}$, Alexander L. Handwerger ${ }^{2,3}$, and Jeffrey S. Munroe ${ }^{1}$ \\ ${ }^{1}$ Geology Department, Middlebury College, Middlebury, 05753, USA \\ ${ }^{2}$ Joint Institute for Regional Earth System Science and Engineering, University of California, Los Angeles, 90095, USA \\ ${ }^{3}$ Jet Propulsion Laboratory, California Institute of Technology, Pasadena, 91109, USA
}

Correspondence: George Brencher (qbrencher@gmail.com)

Received: 18 September 2020 - Discussion started: 2 December 2020

Revised: 19 August 2021 - Accepted: 12 September 2021 - Published: 13 October 2021

\begin{abstract}
Rock glaciers are a prominent component of many alpine landscapes and constitute a significant water resource in some arid mountain environments. Here, we employ satellite-based interferometric synthetic aperture radar (InSAR) between 2016 and 2019 to identify and monitor active and transitional rock glaciers in the Uinta Mountains (Utah, USA), an area of $\sim 3000 \mathrm{~km}^{2}$. We used mean velocity maps to generate an inventory for the Uinta Mountains containing 205 active and transitional rock glaciers. These rock glaciers are 11.9 ha in area on average and located at a mean elevation of $3308 \mathrm{~m}$, where mean annual air temperature is $-0.25^{\circ} \mathrm{C}$. The mean downslope velocity for the inventory is $1.94 \mathrm{~cm} \mathrm{yr}^{-1}$, but individual rock glaciers have velocities ranging from 0.35 to $6.04 \mathrm{~cm} \mathrm{yr}^{-1}$. To search for relationships with climatic drivers, we investigated the timedependent motion of three rock glaciers. We found that rock glacier motion has a significant seasonal component, with rates that are more than 5 times faster during the late summer compared to the rest of the year. Rock glacier velocities also appear to be correlated with the snow water equivalent of the previous winter's snowpack. Our results demonstrate the ability to use satellite InSAR to monitor rock glaciers over large areas and provide insight into the environmental factors that control their kinematics.
\end{abstract}

\section{Introduction}

Rock glaciers are bodies of ice and rock debris that creep downslope due to deformation of their internal ice-rock mixture (Fig. 1) (Wahrhaftig and Cox, 1959; Barsch, 1996). They play an important role in alpine hydrology and landscape evolution, principally through the release of seasonal meltwater and the continuous downslope transport of coarse material (Azócar and Brenning, 2010; Frauenfelder and Kääb, 2000). They also constitute a significant water resource in arid regions (Schaffer et al., 2019), and their importance as a water source is likely to increase with ongoing climate change (Jones et al., 2018a). Understanding how rock glaciers respond to changes in climate is therefore a necessary part of predicting the evolution of cold mountain environments.

Active rock glaciers contain internal ice, exhibit coherent downslope movement over most of their surface, and move downslope at rates on the order of a decimeter to several meters per year (IPA Action Group Rock Glacier Inventories and Kinematics, 2020). Rock glaciers moving at slower rates $\left(<10 \mathrm{~cm} \mathrm{yr}^{-1}\right)$ are defined as transitional and can evolve towards an active or inactive state depending on their topographic and climatic setting (IPA Action Group Rock Glacier Inventories and Kinematics, 2020). Controls on rock glacier kinematics are numerous and include time-dependent water and talus delivery, internal rock glacier structure, bedrock geometry, and short- and long-term changes in ground temperature (Haeberli et al., 2006; Kääb et al., 2007; Ikeda et al., 2008; Delaloye et al., 2010; Müller et al., 2016; Kenner et al., 2017). As with ice glaciers (e.g., Bartholomew et al., 2010; Iverson, 2010; Minchew and Meyer, 2020), tectonic faults (e.g., Bürgmann, 2018) and landslides (e.g., Bayer et al., 2018; Handwerger et al., 2019), liquid water, and pore-water pressure are also important drivers of short-term rock glacier 

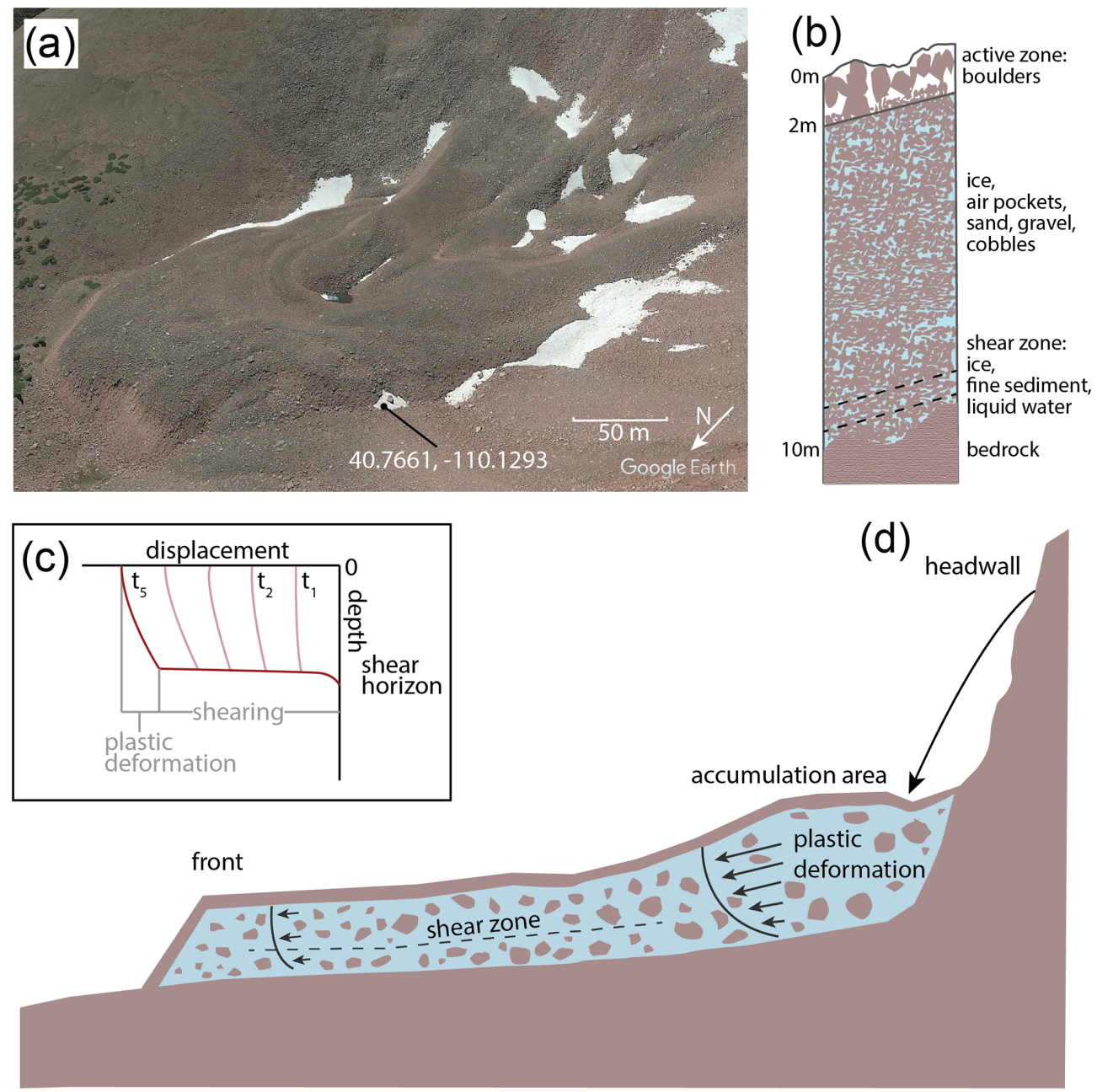

Figure 1. Figure showing general internal structure and deformation of rock glaciers. (a) Oblique view of a Uinta rock glacier from $@$ C Google Earth. (b) Schematic stratigraphic cross section of a rock glacier in the Uinta Mountains. Schematic diagram is based on borehole data from Arenson et al. (2002). (c) Plot showing how total displacement is related to shearing and plastic deformation in rock glaciers. Deformation primarily occurs along shear horizons within rock glaciers. (d) Schematic showing rock glacier deformation (c and $\mathbf{d}$ based on Kenner et al., 2017).

motion (Ikeda et al., 2008; Moore, 2014; Kenner et al., 2017; Eriksen et al., 2018; Cicoira, 2019; Fey and Krainer, 2020).

Rock glacier velocity has been shown to vary over temporal scales ranging from multi-year to hourly (Delaloye et al., 2010; Kenner et al., 2017). For instance, rock glaciers in the European Alps and Norway have undergone significant longterm acceleration in the past few decades attributed to warming permafrost temperatures (Delaloye et al., 2010; Kääb et al., 2007; Kaufmann and Ladstädter, 2007; Roer et al., 2005; Vonder Muehll et al., 2007; Ikeda et al., 2008; Kenner et al., 2017; Eriksen et al., 2018; Fey and Krainer, 2020). On a multi-year timescale, temperature is thought to primarily control variations in rock glacier velocity (Arenson et al., 2002; Haeberli et al., 2006), although differences in precipitation between years may also explain contrasts in rock glacier movement (Ikeda et al., 2008). Seasonal variations in rock glacier motion are also well documented (Haeberli, 1985; Kääb et al., 2003; Arenson et al., 2002) and typically manifest as a strong acceleration in the late spring coincident with melting of snow and ice, followed by a gradual deceleration in the late fall and winter (Perruchoud and Delaloye, 2007; Liu et al., 2013). Recent work suggests that spring acceleration is driven by meltwater infiltration that increases pore-water pressure and reduces frictional strength along shear horizons within rock glaciers (Kenner et al., 2017; Cocoira et al., 2019; Fey and Krainer, 2020). Heavy precipitation and snowmelt events have also been observed to coincide with short-term rock glacier acceleration (Wirz et al., 2016; Kenner et al., 2017).

Access to high-resolution remote sensing imagery and digital topography has improved our ability to inventory rock glaciers over large areas (Krainer and Ribis, 2012; Range- 
croft et al., 2014; Falaschi et al., 2014; Roudnitska et al., 2016; Jones et al., 2018b; Brardinoni et al., 2019). Such datasets are important for assessing the past and current distributions of mountain permafrost, understanding landscape response to climate change following the last glacial maximum, and appraising the regional water storage potential of rock glaciers (Lieb, 1996; Boeckli et al., 2012; Schmid et al., 2015; Zasadni and Kłapyta, 2016; Azócar and Brenning, 2010; Jones et al., 2018a). However, most remotesensing-based inventories have used optical images to identify rock glaciers based on morphology alone and are therefore incapable of determining whether features are currently moving and thus likely contain ice (Munroe, 2018; Nicholson et al., 2009; Lilleøren and Etzelmüller, 2011; KellererPirklbauer et al., 2012; Rangecroft et al., 2014; Roudnitska et al., 2016). Optical imagery is also limited to daytime acquisitions, and snow, shadow, and clouds can obscure features on the ground, sometimes leading to undercounting of rock glaciers (Villarroel et al., 2018).

An alternative approach to inventory rock glaciers is interferometric synthetic aperture radar (InSAR), a remote sensing technique that is not affected by cloud cover, can operate day or night, can sometimes reveal deformation even in the presence of snow, and can detect motion on the millimeter scale (e.g., Liu et al., 2013; Villarroel et al., 2018; Kääb et al., 2021; Strozzi et al., 2020). InSAR does have limitations germane to the study of rock glaciers, including underestimation of true 3D velocities, complications arising from the fixed 1D look direction of the satellite, atmospheric delay, poor correlation caused by changes in ground cover such as snow to snow-free conditions, and errors associated with features moving at velocities greater than the deformation threshold related to the radar wavelength. Many of these can be mitigated by careful study design, however, and at the scale of range-wide analysis, significant patterns in rock glacier kinematics can still be identified.

InSAR has been effectively used to create rock glacier inventories of varying extents and to study rock glacier kinematics (e.g., Nagler et al., 2002; Rignot et al., 2002; Kenyi and Kaufman, 2003; Strozzi et al., 2004; 2020; Lilleøren et al., 2013; Lui et al., 2013; Barboux et al., 2014; Rick et al., 2015; Necsoiu et al., 2016; Wang et al., 2017; Villarroel et al., 2018). Previous InSAR-aided studies of rock glaciers generally fall into two groups: (1) studies that leverage InSAR to facilitate inventorying of large numbers of rock glaciers (e.g., Villarroel et al., 2018, mapped 2116 rock glaciers) over large regions (e.g., Wang et al., 2017, examined an area of $63000 \mathrm{~km}^{2}$ ) or (2) studies that apply InSAR for in-depth kinematic analysis of one or a few rock glaciers (e.g., Rignot et al., 2002; Kenyi and Kaufman, 2003; Necsoiu et al., 2016). We combine these two approaches by inventorying rock glaciers over an area of roughly $3000 \mathrm{~km}^{2}$, estimating velocity for all rock glaciers in our inventory, and performing displacement time series analysis on three representative rock glaciers. Our interpretations of our inventory results and kinematic results inform one another, forming a more comprehensive picture of Uinta rock glacier characteristics and dynamics.

Given the importance of rock glaciers as features of high mountain landscapes, their contribution to mountain hydrology, their ability to act as permafrost indicators, and the remaining open questions about climatic controls on their behavior, additional work is needed to develop the robust understanding of rock glacier dynamics necessary for predicting the response of these features to future climate change (Eriksen et al., 2018). Here, we investigate rock glaciers in the Uinta Mountains (Utah, USA), an important headwater region for the Colorado River in the southwestern USA. Nearly 400 rock glaciers have been visually identified in these mountains, but the presence of ice has been indirectly investigated in only two, limiting understanding of slope processes, hydrology, and permafrost extent in this region (Munroe, 2018). The method of rock glacier identification employed in a previous study by Munroe (2018) involved examining the bases of high-angle bedrock and talus slopes for steep-fronted bulges with reduced lichen cover and ridges and furrows characteristic of rock glaciers using visual imagery at a $1: 5000$ scale. In contrast, we use satellite-based InSAR alongside visual imagery to identify active and transitional rock glaciers and to evaluate controls on their rates of motion over seasonal to multi-annual timescales (20162019). Our work is the first to use satellite InSAR to investigate rock glacier motion in the Uinta mountain range.

\section{Study area}

The Uinta Mountains are an east-west trending mountain range extending over $\sim 3000 \mathrm{~km}^{2}$ in northeastern Utah, USA (Fig. 2). The bedrock of the Uinta Mountains (hereafter, the "Uintas") is Precambrian quartzite, sandstone, and argillite uplifted during the Laramide Orogeny (70-80 Ma) (Bradley, 1936; Sears et al., 1982; Dehler, 2007). While the Uintas are not currently glacierized, during the late Pleistocene, valley glaciers covered more than $2000 \mathrm{~km}^{2}$, creating well-developed glacial geomorphology (Munroe and Laabs, 2009).

Climate at higher elevations in the Uintas $(>3000 \mathrm{~m})$ is periglacial, with a mean annual air temperature (MAAT) from 1981 to 2010 ranging from -4.0 to $3.3^{\circ} \mathrm{C}$ (Fig. 2b). Future climate conditions have not been modeled specifically for the Uintas, but atmosphere-ocean general circulation models for the western US parameterized with the A1B "business as usual" emissions scenario predict an increase in air temperature of about $1.5^{\circ} \mathrm{C}$ by 2030 (IPCC, 2018). Mean annual precipitation (MAP) in the Uintas between 1981 and 2010 ranged from 45 to $107 \mathrm{~cm}$ (Fig. 2c). Most precipitation falls in the winter as snow, of which the largest quantities fall in the western part of the range. The Uintas are an important water resource in the state of Utah, 

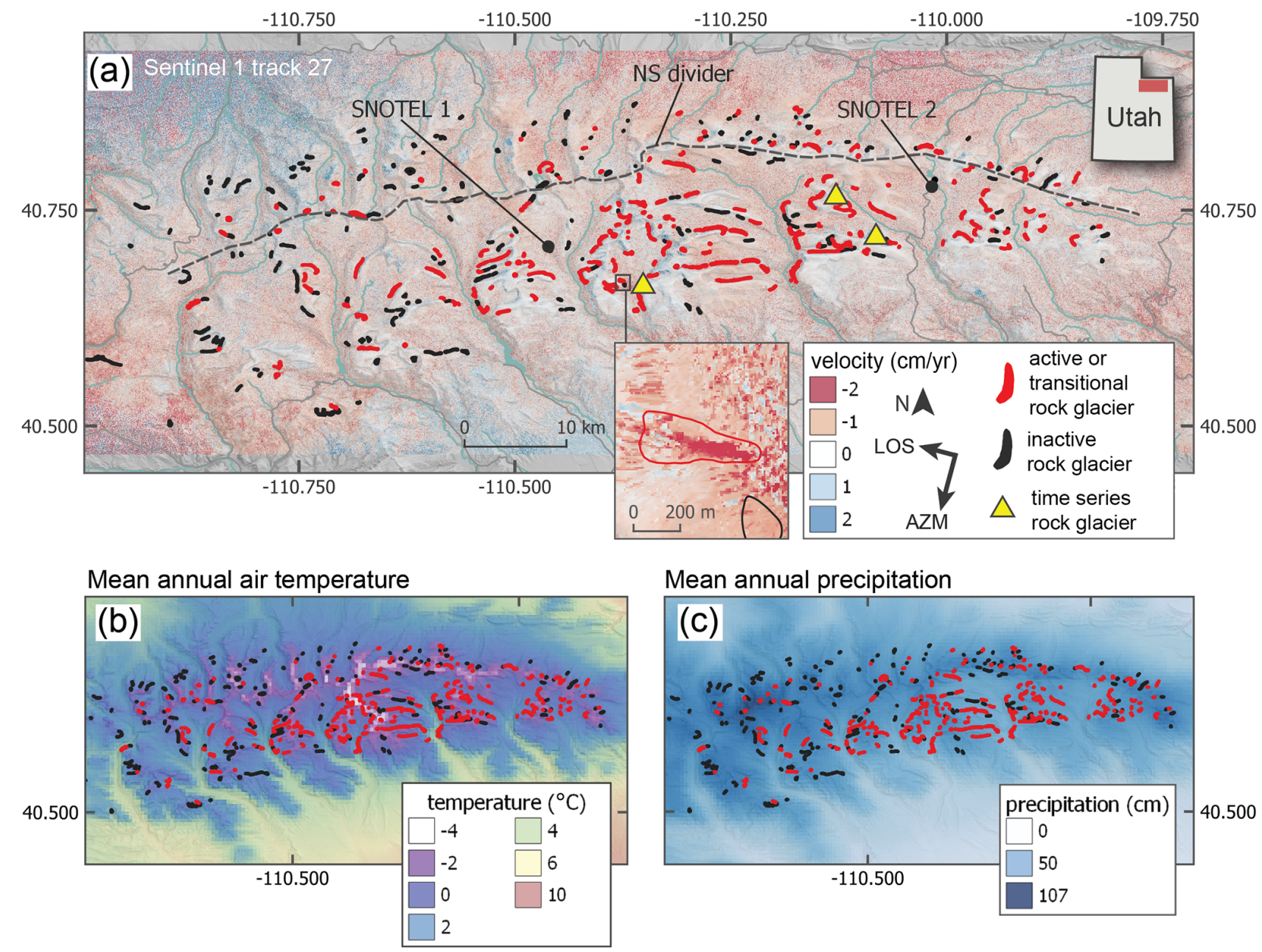

Mean annual precipitation

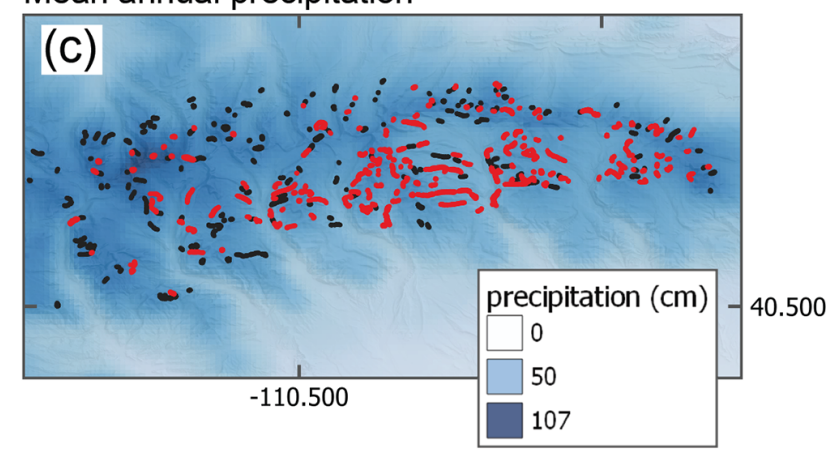

Figure 2. Uinta study site. (a) Hillshade map of the Uinta Mountains overlaid with average 1-year InSAR velocity map derived from descending track 27. Red polygons represent active rock glaciers identified in this study. Black polygons represent rock glaciers identified in the previous inventory (Munroe, 2018) which are inactive (i.e., show no coherent and distinct deformation) in our InSAR velocity maps. Rock glacier size is exaggerated for plotting. SNOTEL 1 is the Five Points Lake station. SNOTEL 2 is the Chepeta station. The dashed black line separates the "North Uintas" from the "South Uintas". Yellow triangles represent the three rock glaciers used in time series analysis, which are, from left to right, the Grayling Lake, Whiterocks River, and Rockflour Lake rock glaciers. Data from USGS, NRCS, and Natural Earth. (b) Mean annual air temperature of the Uinta Mountains. (c) Mean annual precipitation in the Uinta Mountains. In (b) and (c), data are derived from PRISM 30-year normals (1981-2010).

supplying water to 17 counties for municipal, industrial, and agricultural purposes (Tingstad, 2010). Furthermore, calculations indicate that $10 \%-15 \%$ of the Colorado River flow at Lees Ferry, Arizona, is comprised of water from northeastern Utah (Tingstad, 2010). Flow of the Colorado River is expected to decline $10 \%-30 \%$ from 2008 levels in the next 18 to 38 years based on streamflow modeling work, implying intense water deficits in the Colorado River system over the next century (Barnett and Pierce, 2008).

Rock glaciers and talus in the Uintas are estimated to store $0.14 \mathrm{~km}^{3}$ of water or $\sim 10 \%-35 \%$ of the range's annual runoff (Munroe, 2018). These rock glaciers could constitute an even more significant water resource in the coming years as climate change alters temperature and precipita- tion regimes in the western US, particularly during the late summer and autumn when there is less precipitation (MacDonald and Tingstad, 2007). Previous work identified 395 rock glaciers in the Uintas (Munroe, 2018). One of the primary goals of our study was to update this existing inventory, which was based solely on rock glacier morphology, and to identify which of these features are active, transitional, and inactive using the definitions from the IPA Action Group Rock Glacier Inventories and Kinematics (2020). 


\section{Methods}

\subsection{InSAR analysis}

Copernicus Sentinel-1 radar data covering the Uinta Mountains were downloaded from the Alaska Satellite Foundation Vertex website (https://vertex.daac.asf.alaska.edu/, last access: 18 August 2021). We used data acquired in the interferometric wide (IW) swath mode, collected between August 2016 and October 2019. We further selected SAR images acquired when the Uinta rock glaciers appeared to be largely snow-free in optical Planetlab imagery (https://www.planet. com/explorer/, last access: 18 August 2021). We downloaded 26 SAR scenes on ascending track 122 (satellite moving north looking east) and 32 SAR scenes on descending track 27 (satellite moving south looking west). During the snowfree period in 2018, only one ascending and descending track SAR scene was available. Each SAR scene has a pixel size of $14.1 \mathrm{~m}$ in azimuth (i.e., along-track direction) and $2.3 \mathrm{~m}$ in range (i.e., look direction).

Interferograms were processed in the JPL InSAR Scientific Computing Environment (ISCE) version 2 software (Rosen et al., 2012) with two looks in range and one look in azimuth, resulting in a $\sim 5 \mathrm{~m}$ by $\sim 14 \mathrm{~m}$ pixel size. Within a given summer (i.e., snow-free period), all possible combinations of interferograms were processed (Fig. A1; Table A1). Late summer scenes were combined with scenes from the following summers to create year-long pairs that bridge the winter when the ground is covered in snow. In total we created 45 ascending pairs and 63 descending pairs for a total of 108 interferograms. The minimum time between pairs was $6 \mathrm{~d}$, and the maximum time was $756 \mathrm{~d}$, with a median of $48 \mathrm{~d}$. We used a Shuttle Radar Topography Mission (SRTM) DEM with $\sim 30 \mathrm{~m}$ pixel spacing to remove topographic signal from the phase and to geocode the interferograms. In addition, selected 1-year interferogram pairs were reprocessed with a USGS 3DEP DEM with $10 \mathrm{~m}$ pixel spacing. The primary reason we reprocessed these selected pairs was to improve spatial resolution in order to more accurately inventory the moving rock glaciers (Table A1). However, computational limitations prevented us from processing all 108 interferograms with the $10 \mathrm{~m}$ DEM. Interferograms were unwrapped using the Statistical-Cost, Network-Flow Algorithm for Phase Unwrapping (SNAPHU) (Chen and Zebker, 2002). We applied a correlation threshold of 0.3 during unwrapping to remove low-quality data.

Many of the interferograms suffered from topographycorrelated atmospheric effects that obscured signals of rock glacier deformation. These atmospheric effects result from differences in pressure, temperature, and relative humidity in the lower troposphere, causing radar to refract variably over the land surface and producing a two-way phase delay (Bekaert et al., 2015). We applied a tropospheric phase delay correction based on pressure, temperature, and humidity predictions from the ERA-I global weather model, which outputs data at a spatial resolution of $80 \mathrm{~km}$ on a $6 \mathrm{~h}$ interval (Bekaert et al., 2015). The correction was done using the TRAIN software package (Toolbox for Reducing Atmospheric InSAR Noise) from Bekaert et al. (2015).

All resulting InSAR velocity maps were used along with Google Earth imagery, the USGS $10 \mathrm{~m}$ DEM, and the previous Uinta rock glacier inventory (Munroe, 2018) to generate a new rock glacier inventory in QGIS 3.10. We inventoried rock glaciers displaying a clear and relatively high line-ofsight (LOS) velocity signal with a sign suggesting downslope movement (Fig. 2). The smallest spatial area we considered to have a clear and coherent signal indicating rock glacier activity was $5000 \mathrm{~m}^{2}$. Rock glaciers identified in the Munroe (2018) inventory that showed no coherent and distinct deformation in our InSAR velocity maps were classified as inactive. Boundaries of rock glaciers were manually delineated on the basis of morphology and InSARderived movement pattern. Slope, aspect, and elevation of features in the rock glacier inventory were calculated in QGIS from the $10 \mathrm{~m}$ DEM. Rock glaciers were classified as lobate (width $>$ length) or tongue-shaped (length $>$ width) (Barsch, 1996) based on morphology. We also grouped the rock glaciers into "North Uintas" or "South Uintas" based on their location relative to the east-west trending spine of the mountain range (Fig. 2). A non-parametric Kruskal-Wallis test with a significance threshold of 0.05 was used to establish significance of differences between all rock glacier groups.

Average annual velocities for rock glaciers were calculated in QGIS using velocity maps derived from ascending and descending stacks of 1-year interferograms (Fig. 2). These stacks were calculated from the 1 -year pairs with $10 \mathrm{~m}$ pixel spacing (Table A1). Average LOS velocity magnitudes were calculated by taking the mean of the absolute value of velocity values over the surface of each rock glacier. We then defined characteristic LOS rock glacier velocities as the 75th percentile of the absolute value of velocity values within a mapped rock glacier body. This approach was used to deemphasize noisy areas that could contain erroneous high or low velocities and to highlight the velocity of the active part of each rock glacier (Bayer et al., 2018; Handwerger et al., 2019). For both mean and 75th percentile velocity, two values were generated for each rock glacier: one derived from the ascending and another from the descending stack.

To quantify uncertainty, InSAR-derived LOS velocities for 12 mostly flat, roughly rock-glacier-sized control areas were calculated using the absolute value of the same ascending and descending stacks used to calculate rock glacier velocity. We assumed these control areas are stable (i.e., not deforming), and therefore any apparent deformation is due to uncertainty.

In addition to our LOS velocity estimates, we calculated ground surface velocity estimates for each rock glacier by projecting our LOS estimates onto the downslope direction using the method described in Liu et al. (2013). This approach assumes that rock glaciers are flowing uniformly 


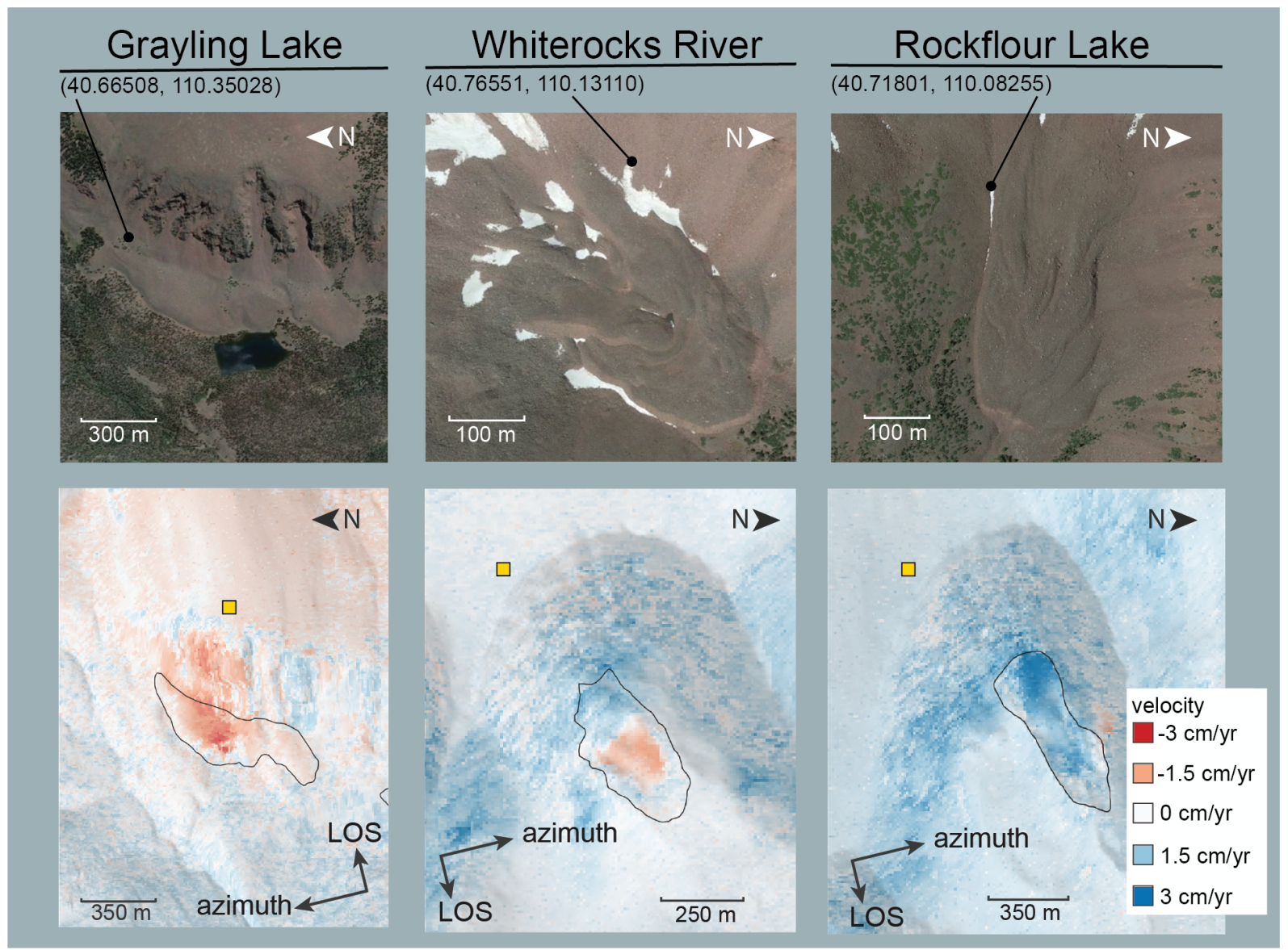

Figure 3. Individual rock glaciers investigated with time series. (Top) Overhead view of rock glaciers in () Google Earth, annotated in Adobe Illustrator. (Bottom) Average velocity stack draped over a hillshade. Rock glaciers were added to our active inventory if they displayed clear deformation signal, like those above. Yellow squares represent stable local reference points used in our time series analysis.

along their average azimuth and slope direction. The heading angle and incidence angle of the satellite are $\sim 12^{\circ}$ (positive counterclockwise from north) and $\sim 41^{\circ}$ for the ascending track and $\sim 168^{\circ}$ and $\sim 40^{\circ}$ for the descending track. The USGS $10 \mathrm{~m}$ DEM was used to calculate average slope angle and average azimuth angle for each rock glacier, and the 75th percentile LOS velocities were used to represent LOS velocity. The larger of the resulting ascending and descending values is used to represent rock glacier velocity in our analysis.

Lastly, we performed time series inversions for three representative rock glaciers selected on the basis of their clear deformation signal in the average velocity stack: Grayling Lake, Whiterocks River, and Rockflour Lake (Fig. 3). Time series were calculated for these rock glaciers using the small baseline subset (SBAS) method (Berardino et al., 2002; Schmidt and Bürgmann, 2003). Interferograms with low overall coherence were manually removed from the time series. Stable local reference points for each rock glacier were chosen using Google Earth imagery to identify nearby ridge tops (Fig. 3).

\subsection{Climate data}

Climatic data relevant to the rock glacier inventory were obtained by two sources: Parameter-elevation Regressions on Independent Slopes Model (PRISM; PRISM Climate Group, 2004, Oregon State University, http://prism.oregonstate.edu, last access: 18 August 2021) and Snow Telemetry (SNOTEL; https://www.wcc.nrcs.usda.gov/snow/, last access: $18 \mathrm{Au}$ gust 2021). PRISM data were used to establish the temperature and precipitation envelope of the rock glacier inventory. We downloaded 30-year-normal (1981-2010) mean temperature and precipitation rasters with $800 \mathrm{~m}$ pixel spacing for each month with the PRISM package in R and used them to calculate mean annual air temperature (MAAT) and precipitation (MAP) for each rock glacier in the inventory. SNOTEL data (1980-2020) were used to constrain meteorological conditions during the intervals represented by the cumulative displacement time series. The Chepeta SNOTEL, at an elevation of $3200 \mathrm{~m}$, is $10.0 \mathrm{~km}$ from the Whiterocks River rock glacier $(3460 \mathrm{~m})$ and $8.1 \mathrm{~km}$ from the Rockflour Lake rock glacier (3301 m) (Fig. 2). The Five Points Lake SNO- 
TEL, at an elevation of $3335 \mathrm{~m}$, is $11.8 \mathrm{~km}$ from the Grayling Lake rock glacier $(3101 \mathrm{~m})$.

\section{Results}

\subsection{Rock glacier inventory}

Our inventory contains 205 rock glaciers totalling $24.3 \mathrm{~km}^{2}$ that are found at an average elevation of $3307 \pm 169 \mathrm{~m}$ ( \pm corresponds to 1 standard deviation) (Fig. $4 \mathrm{~d}$ ). The rock glaciers average $11.9 \pm 11.0 \mathrm{ha}$ in area; $7 \%$ are $>30 \mathrm{ha}$, with a maximum of 60.2 ha (Fig. 4a). Their average slope is $22.1^{\circ} \pm 4.6^{\circ}$ (Fig. $4 \mathrm{~g}$ ). The rock glaciers most frequently face north $(20.5 \%)$, followed by northeast $(17.5 \%)$, and east $(12.2 \%)$ (Fig. 5a and b). For reference, steep slopes of the Uintas $\left(>10^{\circ}\right)$ face generally north $(18.7 \%)$ and south $(19.6 \%)$ (Fig. 5c).

Morphologically, $78.5 \%$ of the rock glaciers are lobate, and $21.5 \%$ are tongue-shaped. Tongue-shaped rock glaciers are found at average elevations of $3384 \pm 192 \mathrm{~m}$, significantly higher than lobate rock glaciers, which are found at average elevations of $3286 \pm 156 \mathrm{~m}(n=205, p=0.000)$ (Fig. 4e). Lobate rock glaciers average $13.1 \pm 11.9$ ha in area, significantly larger than tongue-shaped rock glaciers, which are $7.40 \pm 4.15$ ha on average ( $n=205, p=0.017)$ (Fig. 4b). All rock glaciers $>20$ ha in area are lobate rock glaciers, and morphology is not correlated with rock glacier slope or aspect.

A total of 44 rock glaciers ( $21.5 \%$ of the inventory) are located on the north side of the Uintas. These features are found at average elevations of $3361 \pm 102 \mathrm{~m}$, significantly higher than the 161 rock glaciers located on the south side, which are found at $3292 \pm 180 \mathrm{~m}(n=205, p=0.0177)$ (Fig. 4f). Rock glaciers on the north side tend to face broadly northeast, with $43.2 \%$ facing north and $25.0 \%$ facing northeast, while rock glaciers on the south side do not appear to prefer a specific aspect as strongly. Area and slope angle are not significantly different for North and South Uintas rock glaciers (Fig. 4c and i). Tongue-shaped rock glaciers make up a larger proportion of North Uintas rock glaciers (31.8\%) than the South Uintas rock glaciers (18.6\%).

\subsection{Rock glacier temperature and precipitation}

Given the PRISM dataset, rock glaciers are found at an average MAAT of $-0.25 \pm 1.08^{\circ} \mathrm{C}$ (Fig. $4 \mathrm{j}$ ). A total of $90.7 \%$ of the rock glaciers are found at MAATs above $-1.5^{\circ} \mathrm{C}$. Average MAAT at lobate rock glaciers is $-0.13 \pm 1.0^{\circ} \mathrm{C}$, significantly higher than tongue-shaped rock glaciers, which are found at an average MAAT of $-0.66 \pm 1.2^{\circ} \mathrm{C}(n=205$, $p=0.000$ ) (Fig. 4k).

Rock glaciers receive an estimated average of $75.0 \pm$ $8.47 \mathrm{~cm}$ of precipitation per year (Fig. $4 \mathrm{~m}$ ), of which $~$ $29 \%-40 \%$ is rain and $\sim 60 \%-71 \%$ is snow. North Uinta rock glaciers receive on average $81.6 \pm 7.85 \mathrm{~cm}$, significantly
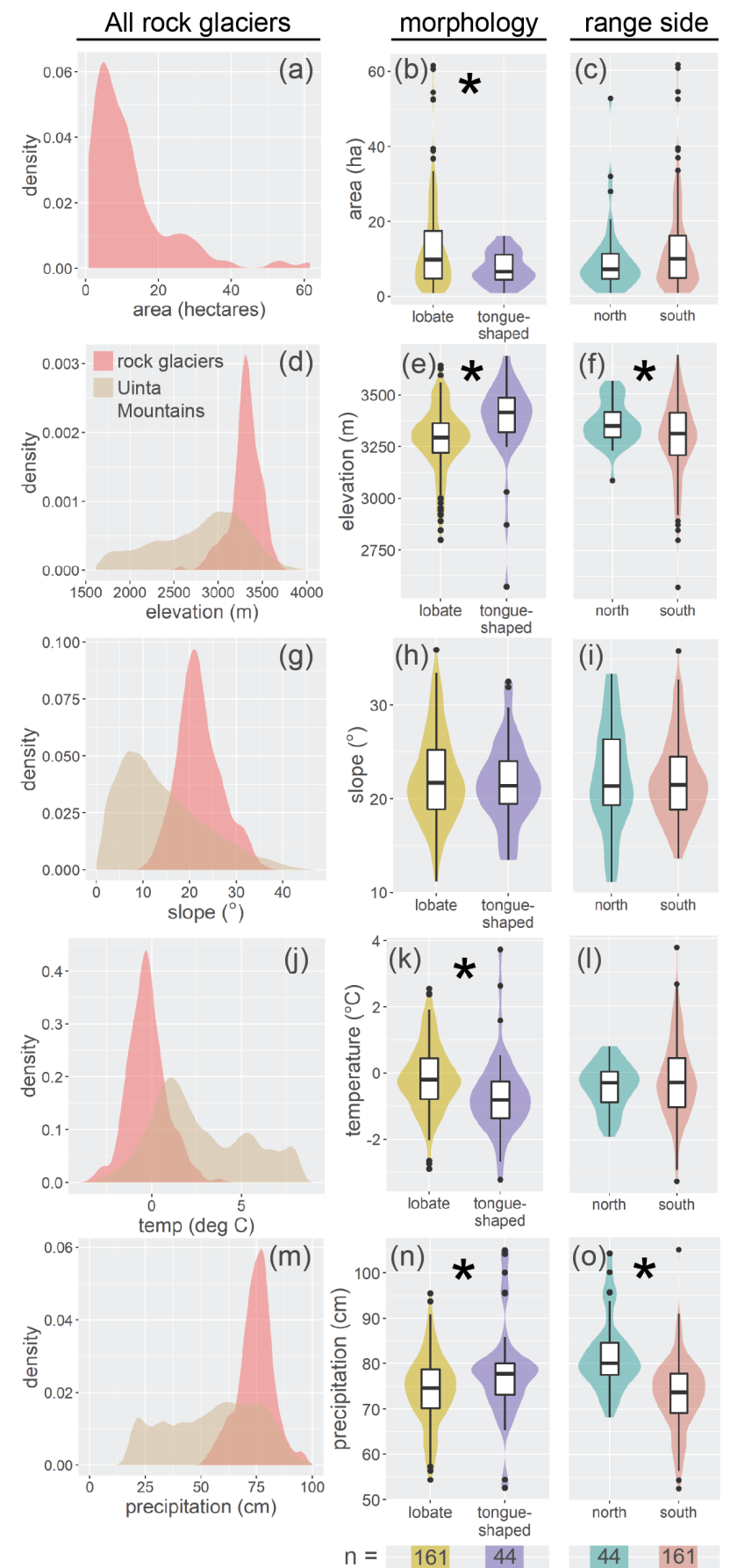

Figure 4. Characteristics of active rock glaciers in the Uinta Mountains. Slope, area, and elevation were calculated using the rock glacier inventory polygons and a DEM in QGIS. Temperature and precipitation were calculated using the rock glacier inventory polygons and PRISM data in QGIS. (a, $\mathbf{d}, \mathbf{g}, \mathbf{j}, \mathbf{m})$ Data for all rock glaciers and the Uinta Mountains shown as kernel density plots. (b, $\mathbf{c}, \mathbf{e}, \mathbf{f}, \mathbf{h}, \mathbf{i}, \mathbf{k}, \mathbf{l}, \mathbf{n}, \mathbf{o})$ Colored violin plots on the right show rock glacier characteristics based on morphology and location within the Uintas. Asterisks denote statistically significant differences, and $n=205$. 


\section{rock glacier aspect}
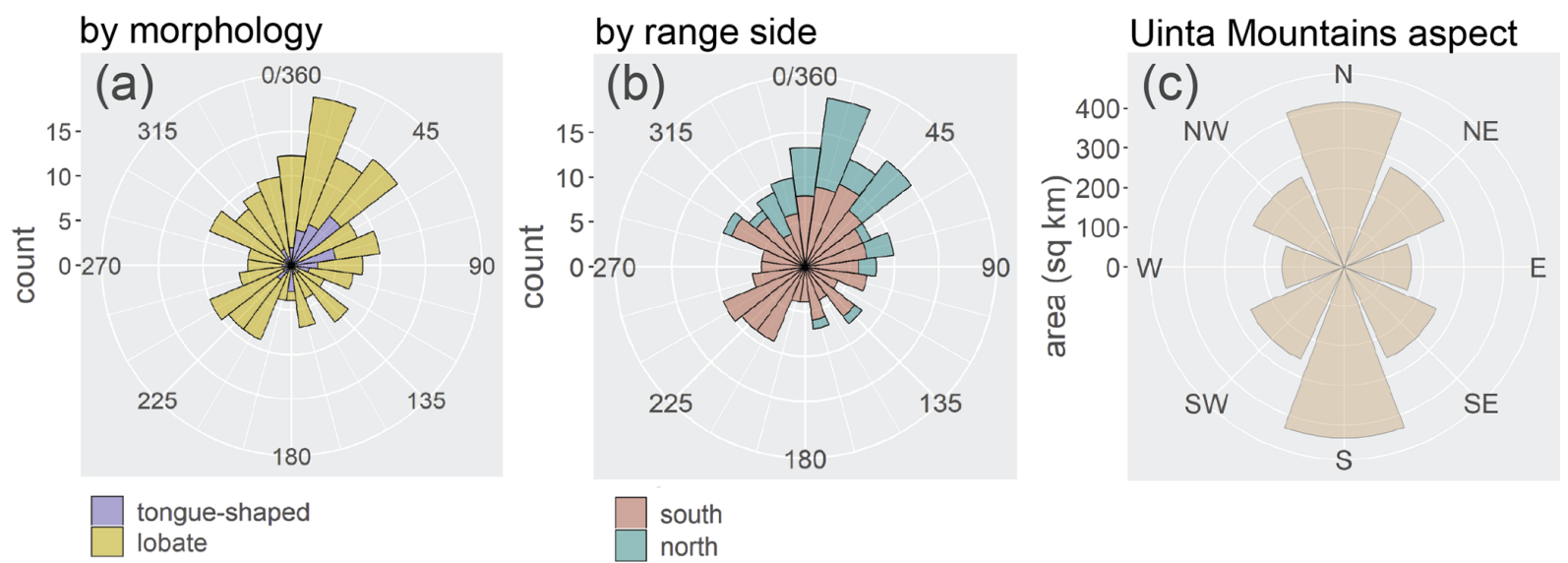

Figure 5. Polar plots showing aspect of active rock glaciers from the Uinta Mountains inventory and aspect of the steep slopes $\left(>10^{\circ}\right)$ of the Uinta Mountains. (a) Aspect is classified by rock glacier morphology. (b) Aspect is classified by which side of the Uinta Mountains the rock glacier is on. (c) Aspect of steep slopes $\left(>10^{\circ}\right)$ of the Uinta Mountains, for reference. Data are derived from rock glacier inventory polygons and a USGS DEM.

more than South Uinta rock glaciers, which receive $73.2 \pm$ $7.72 \mathrm{~cm}(n=205, p=0.000)$ (Fig. 4o). Tongue-shaped rock glaciers receive $77.8 \pm 10.4 \mathrm{~cm}$, significantly more than the $74.2 \pm 7.73 \mathrm{~cm}$ received by lobate rock glaciers $(n=205$, $p=0.031)$.

\subsection{Inactive rock glaciers}

Of the rock glaciers identified during this study and previously by Munroe (2018), 199 are inactive based on our InSAR velocity maps. These inactive rock glaciers, which total $12.9 \mathrm{~km}^{2}$, average $6.5 \pm 6.3 \mathrm{ha}$ in area, and are found at an average elevation of $3269 \pm 142 \mathrm{~m}$ (Fig. 6a and b). Their average MAAT is $0.035 \pm 0.91^{\circ} \mathrm{C}$, and average MAP is $78.3 \pm 8.82 \mathrm{~cm}$ (Fig. $6 \mathrm{c}$ and d). They are significantly smaller than the active and transitional rock glaciers and receive significantly more precipitation (area, $n=404, p=0.000$; precipitation, $n=404, p=0.000$ ) (Fig. 6a and d). They also experience significantly higher MAATs $(n=404, p=0.001)$ (Fig. 6c) and are found at significantly lower elevations $(n=$ $404, p=0.002$ ). They face north most commonly, $22.6 \%$ of the time, followed by south, $17.1 \%$ of the time. They face north slightly more often than active and transitional rock glaciers, which face north $20.5 \%$ of the time.

\subsection{Rock glacier velocity}

Uinta rock glaciers generally have non-uniform spatial velocity patterns. On their rooting zone, rock glacier velocity tends to be highly heterogenous, varying over $\sim 10 \mathrm{~m}$ length scales. On the main body of the rock glaciers, velocity is typically more homogenous, with one or more high velocity patches surrounded by areas of a lower velocity. For many rock glaciers, these high-velocity patches occupied only a small portion of the total surface area of the rock glacier. In projecting rock glacier velocities downslope, 75th percentile LOS velocities were scaled by a factor between 1.06 and 6.10. The characteristic downslope velocity from 2016 to 2019 was $1.94 \pm 1.16 \mathrm{~cm} \mathrm{yr}^{-1}$ (Fig. 7b). The fastest rock glacier velocities occurred during August each year, when several rock glaciers had maxima above $40 \mathrm{~cm} \mathrm{yr}^{-1}$. No metric of rock glacier velocity is significantly correlated with rock glacier area, elevation, slope, or type (i.e., lobate or tongue-shaped) (Figs. 7a and A2). North- and south-facing rock glaciers had higher downslope velocities than broadly east- and west-facing rock glaciers (Fig. A2f).

We approximated uncertainty in the InSAR velocity by quantifying the apparent velocity of 12 stable control areas. We found that average LOS velocities for stable areas was $0.33 \pm 0.12$ and $0.62 \pm 0.32 \mathrm{~cm} \mathrm{yr}^{-1}$ for ascending and descending stacks, respectively.

Time series for the three representative rock glaciers show time-dependent deformation from 2016 to 2019 (Fig. 8ac). Each of these rock glaciers had faster LOS velocities during snow-free observation periods than during snowcovered periods ( $n=30, p=0.001)$ (Fig. 8d). For example, the Grayling Lake rock glacier averaged $4.97 \mathrm{~cm} \mathrm{yr}^{-1}$ during snow-free observation periods and $0.83 \mathrm{~cm} \mathrm{yr}^{-1}$ during snow-covered periods.

In addition to seasonal changes in velocity, the Rockflour Lake rock glacier experienced a strong deceleration throughout 2018 (Fig. 8c). This rock glacier appears to have ceased motion in the winter of 2017/18 and only displaced $0.11 \mathrm{~cm}$ during the subsequent summer, fall, and winter of 2018. Yet during the same time period in 2016 and 2017, this rock glacier displaced 4.0 and $1.79 \mathrm{~cm}$, respectively. This change 

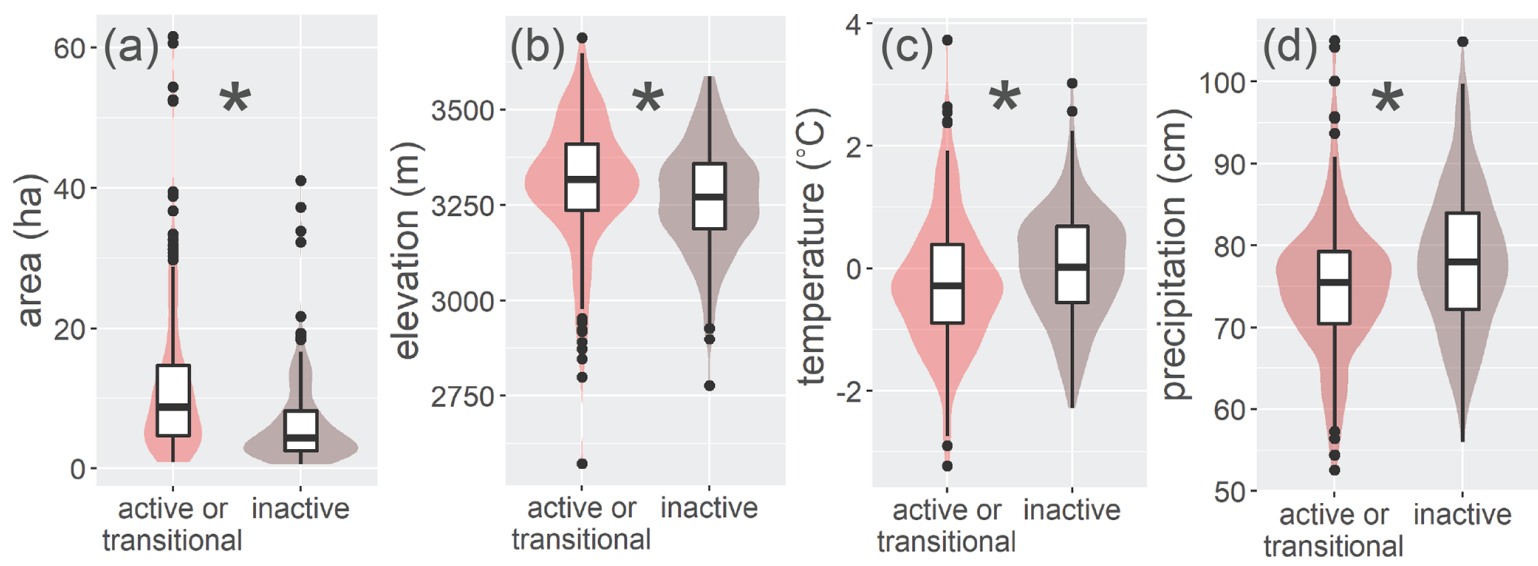

Figure 6. Violin plots comparing active rock glaciers with inactive rock glaciers from the previous Uinta rock glacier inventory. Asterisks denote statistically significant differences, and $n=404$.

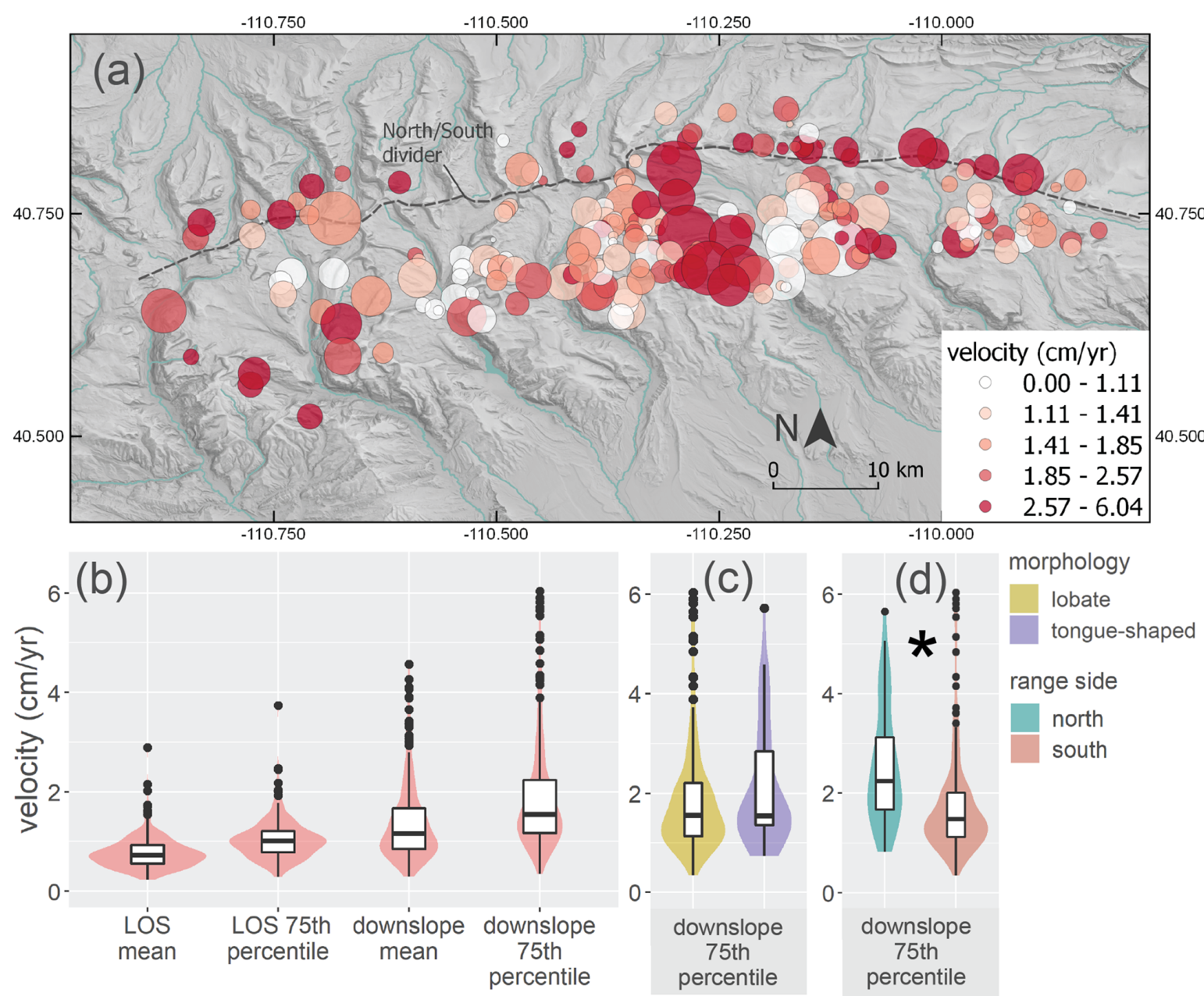

Figure 7. Average annual downslope velocities of active Uinta rock glaciers from 2016 to 2019. (a) Map showing rock glacier area and velocity. Each rock glacier is represented by a circle. Size of circle represents relative rock glacier area, and color represents absolute value of rock glacier 75th percentile downslope velocity. Note fewer, smaller, slower rock glaciers in the North Uintas. (b) Violin plots show absolute value of mean and 75th percentile LOS and downslope velocities for all rock glaciers. (c) Violin plots show 75th percentile downslope velocities for rock glaciers classified by morphology. (d) Violin plots show 75th percentile downslope velocities for rock glaciers classified by which side of the Uinta Mountains they are on. Asterisks denote significant differences, and $n=205$. 


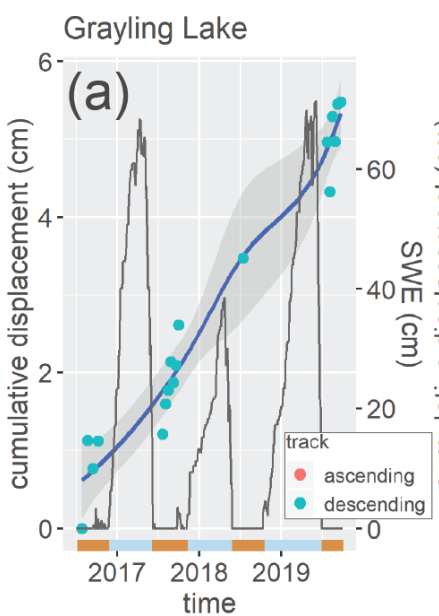

Whiterocks River

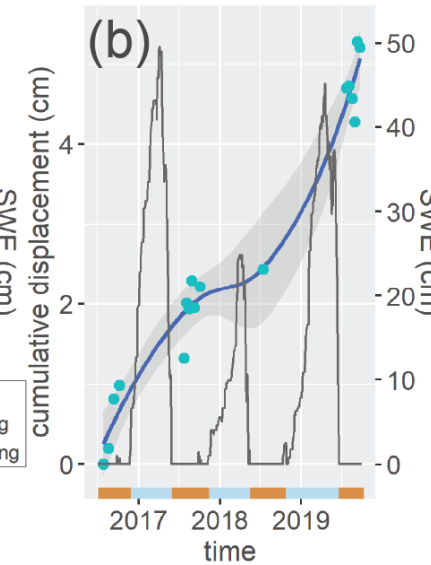

Rockflour Lake

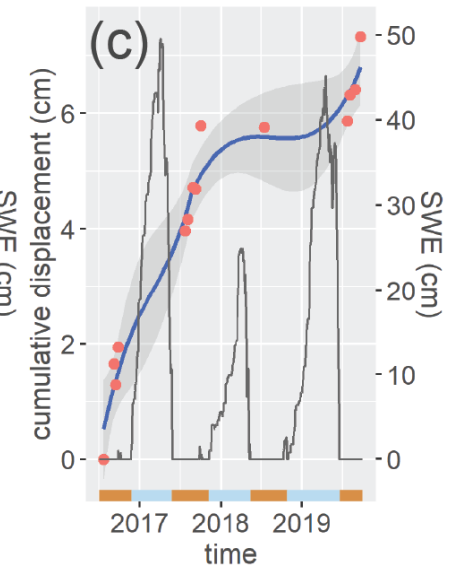

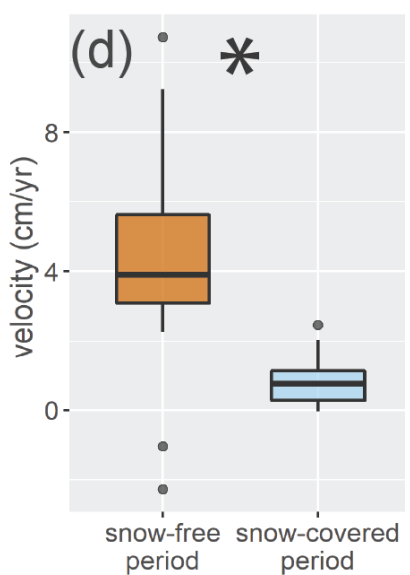

Figure 8. Displacement time series for three representative rock glaciers. (a-c) Time-dependent displacement of three rock glaciers from 2016 to 2019 and snow water equivalent (SWE) from nearby weather stations. Blue and orange bars along the $x$ axes denote snow-free (orange) and snow-covered (blue) periods. Ascending and descending LOS are scaled so they are both positive and increasing. Time series displacement values were calculated using an average of 9 pixels $\left(8100 \mathrm{~m}^{2}\right.$ total area) in the rock glacier. Interferograms with low overall coherence were manually removed from the time series. Gray shaded regions around trend lines are $95 \%$ confidence intervals. (d) LOS velocities of three rock glaciers during the snow-free period in late summer compared to the snow-covered period from October to July; $n=30$, and $p=0.001$.

Five Points Lake SNOTEL

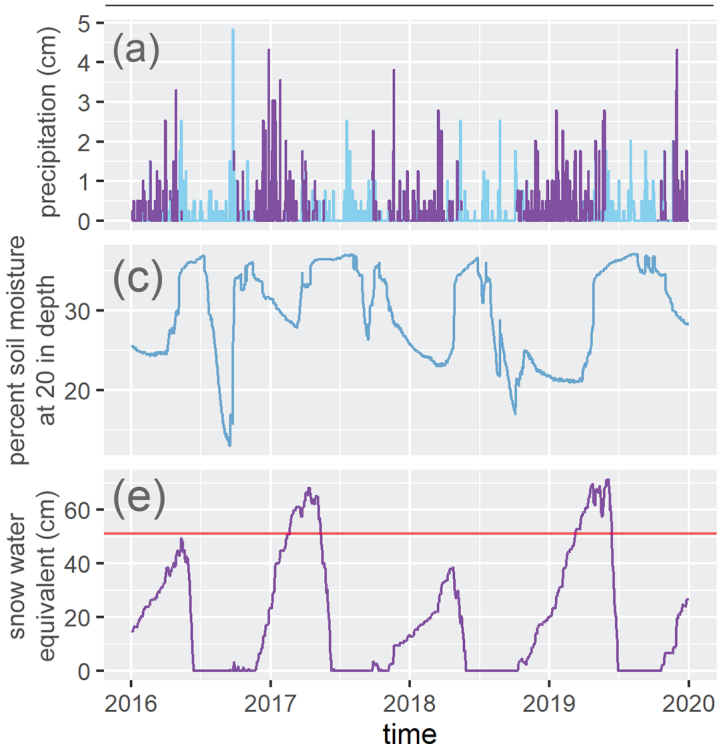

\section{Chepeta SNOTEL}
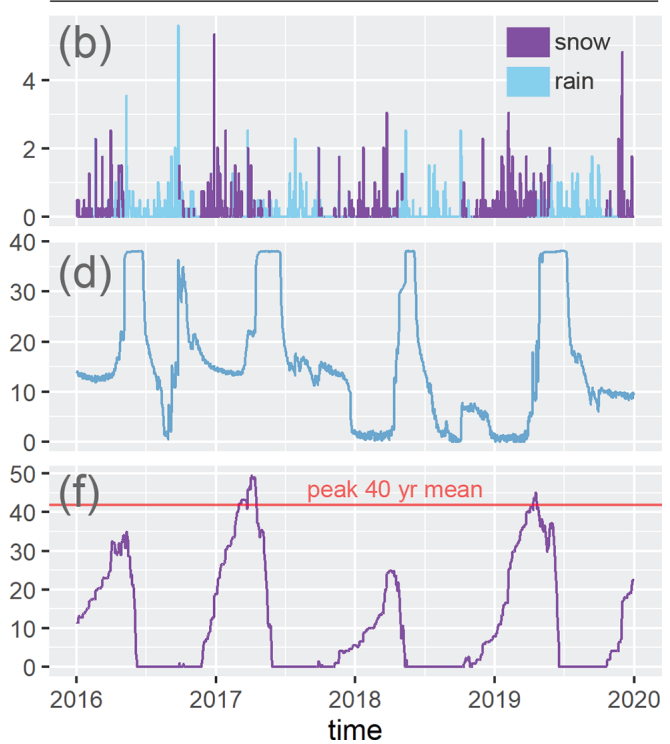

Figure 9. Precipitation, soil moisture, soil temperature, and snow water equivalent (SWE) at the Five Points Lake and Chepeta SNOTEL stations from 2016 to 2019. (a, b) Precipitation events. Purple lines represent snow, and blue lines represent rain. Precipitation type was inferred from average daily temperature at the SNOTEL station. (c, d) Percent soil moisture at 20 in $(50.8 \mathrm{~cm})$ depth. (e, f) SWE. Red lines represent average peak SWE over the past 40 years.

in behavior corresponds temporally with a reduced spring melt caused by a small winter snowpack (Fig. 9).

\section{Discussion}

\subsection{The rock glacier niche}

The rock glacier inventory we created reveals the locations of active and transitional rock glaciers in the Uintas and illuminates the conditions necessary for rock glacier formation and 
sustained creep. Although the Uintas extend from elevations of $\sim 2200$ to $>4100 \mathrm{~m}, 77.1 \%$ of rock glaciers are found in a narrow elevation band between 3100 and $3500 \mathrm{~m}$. This zone has a MAAT from 0.5 to $-2{ }^{\circ} \mathrm{C}$, at which talus production is likely high due to frost-cracking (Hales and Roering, 2007; Rempel et al., 2016). Deposition of fresh talus onto the rock glacier source area helps sustain rock glacier motion (Barsch, 1996; Müller et al., 2016). The comparison between our active and transitional rock glacier inventory and the inactive rock glaciers identified by the previous inventory (Munroe, 2018) demonstrates the sensitivity of Uinta rock glaciers to temperature. Active and transitional rock glaciers are found at higher elevations than inactive rock glaciers and have a subzero median MAAT, whereas inactive rock glaciers have a median MAAT above zero (Fig. 6c). Rock glaciers can become inactive for myriad reasons, but almost all are related to insufficient internal ice or insufficient talus supply (Barsch, 1996). Both talus production and stability of internal ice are related to temperature, as freeze-thaw cycles strongly control erosion, and temperature is the primary control on permafrost stability (Hales and Roering, 2007; Hinzman, 1998). Depending to some extent on local conditions, permafrost begins to degrade at MAATs above $0{ }^{\circ} \mathrm{C}$ (Hoelzle and Haeberli, 1995), reducing ice content and rendering rock glaciers inactive.

Tongue-shaped rock glaciers are found at significantly higher elevations than lobate rock glaciers. Noting a similar trend in the Colorado Front Range, Janke (2007) concluded that high-elevation tongue-shaped rock glaciers evolve from ice glaciers that become covered by debris. We cannot evaluate this theory with our data; however, in the Uintas, welldeveloped cirques are found mostly at high elevations (> $3250 \mathrm{~m}$ ), while steep valley walls continue down below the elevation where active rock glaciers are observed (Munroe and Laabs, 2009). Tongue-shaped rock glaciers are mostly found in these high-elevation cirques, which, as a function of their geometry, may simply be more likely to produce tongue-shaped rock glaciers if debris is supplied from a narrow zone at the base of the cirque headwall (Degenhardt, 2009). In contrast, lobate rock glaciers are mostly found along valley walls, where debris is produced more consistently across a wider area (Degenhardt, 2009).

The geometry of the Uintas can explain other trends in rock glacier location. For instance, active and transitional rock glaciers in the North Uintas preferentially face northeast, while active and transitional rock glaciers in the South Uintas appear to have no strong preference for aspect. This north-facing trend in North Uintas rock glaciers is likely related to slope patterns. The North Uintas are steeper than the South Uintas; as such, high elevation terrain is less extensive and is found closer to the main east-west trending spine of the range. Thus, most rock glaciers in the North Uintas root on the east-west trending spine and flow northward, down-gradient. In the South Uintas, active and transitional rock glaciers face all directions in relatively equal proportions. Given that north-facing slopes are less common than south-facing slopes on the south side of the range, South Uintas rock glaciers do face north more often than expected if rock glaciers were distributed randomly over steep mountain slopes. Rock glaciers may preferentially face north due to decreased sunlight exposure on north-facing slopes, which decreases local temperatures (Munroe, 2018). This trend has been reported for other North American rock glaciers (e.g., Luckman and Crockett, 1978; Janke et al., 2007; Johnson et al., 2007; Liu et al., 2013)

The interaction between Uinta geometry and temperature further seems to control rock glacier morphology. In the North Uintas, $31.8 \%$ of rock glaciers are tongue-shaped, whereas in the South Uintas, $18.6 \%$ of rock glaciers are tongue shaped. In the gently sloping South Uintas, even valley walls far from the central spine of the mountains are at low enough temperatures to support rock glaciers, while in the steeper North Uintas, valley wall sites an equal distance from the crest have MAATs well above $0{ }^{\circ} \mathrm{C}$ and cannot support rock glaciers (Fig. 2b). These valley walls are associated with more lobate rock glaciers than tongue-shaped rock glaciers. The well-developed cirques associated with tongueshaped rock glaciers, on the other hand, do not extend far from the spine of the Uintas. Thus, in the South Uintas, lobate rock glaciers are more common than tongue-shaped rock glaciers. In the steeper North Uintas, cirques and valley walls are in more equal proportion in the subzero MAAT zone, explaining the increased relative abundance of tongue-shaped rock glaciers.

\subsection{Rock glacier velocity}

Moving rock glaciers in the Uintas deform downslope at rates between 0.35 and $6.04 \mathrm{~cm} \mathrm{yr}^{-1}$, with the average feature deforming $1.94 \mathrm{~cm} \mathrm{yr}^{-1}$. This range of mean velocities is lower than velocities reported for other rock glaciers in the western US and the Alps (Janke et al., 2005; Delaloye et al., 2010). We note, however, that rock glacier velocities are often calculated using different methods. Our velocity measurements correspond to average annual rock glacier velocity; thus, they average over seasonal changes such as the typical winter deceleration. Additionally, in many cases, only a small portion of a large rock glacier is moving. Nonetheless, even after accounting for underestimates produced by our methods, it remains notable that rock glaciers in the Uintas appear to be moving nearly an order of magnitude slower than most other North American rock glaciers (Table 1 in Janke et al., 2005). Almost all moving Uinta rock glaciers would most accurately be described as transitional as opposed to active based on the guidelines from the IPA Action Group Rock Glacier Inventories and Kinematics (2020).

Rock glaciers are sensitive to numerous variables that could differ between mountain ranges, possibly influencing rock glacier velocity; these include temperature and precipitation regime (Ikeda, et al., 2008; Eriksen et al., 2018) and 
talus characteristics and delivery rate (Arenson et al., 2002; Müller et al., 2016). However, despite the broad range of temperature and precipitation conditions throughout the Uintas, there is no apparent relationship between velocity and local MAAT or MAP. Furthermore, if talus characteristics have a strong influence on Uinta rock glacier velocities, we would expect adjacent rock glaciers which receive talus derived from the same bedrock units to have similar velocities. However, slow rock glacier velocities were observed throughout the Uintas, with little local grouping of similar velocities in a manner reflecting bedrock composition (Fig. 7a). Thus, the generally low velocities measured for Uinta rock glaciers are not likely due to consistent differences in climate or talus delivery relative to other mountain ranges. An alternative explanation for low rock glacier velocities in the Uintas is comparatively smaller quantities of internal ice. Most Uinta rock glaciers are found at MAATs close to $0{ }^{\circ} \mathrm{C}$, based on 30-year temperature normals from 1980 to 2010 . Thus, many rock glaciers may have experienced a negative mass balance of internal ice as temperatures warmed over the past decade.

Overall, Uinta rock glacier kinematics are complex and defy simple correlation with rock glacier area, elevation, slope, aspect, or morphology (Fig. A2). These factors likely interact to influence rock glacier rheology alongside additional variables including talus, snow, and meltwater delivery rate, clast size, underlying bedrock geometry, temperature, thickness, pore space, ice content, and shear zone geometry (Haeberli et al., 2006). Complex relationships between kinematics and external and internal factors make it especially challenging to predict rock glacier motion. This reality underscores the benefit of using InSAR (or other remotesensing-based kinematic data) to generate rock glacier inventories, allowing for quantifiable observation of rock glacier displacement.

\subsection{Limitations of InSAR and uncertainty analysis}

We encountered some limitations of InSAR that require consideration. The insensitivity of InSAR to movement along the satellite flight direction (i.e., perpendicular to the LOS direction) made it difficult to determine whether some northor south-facing rock glaciers were actively deforming. This may have produced a bias in our inventory toward rock glaciers flowing broadly eastward or westward. In the prior Uinta rock glacier inventory based on morphological data (Munroe, 2018), 22.6\% of rock glaciers face north, while $17.1 \%$ of rock glaciers faced south. In our active and transitional rock glacier inventory, $20.5 \%$ of rock glaciers faced north, and $7.32 \%$ of rock glaciers faced south. South-facing rock glaciers may be more likely to become inactive due to increased sunlight exposure, elevated local temperatures, and consequent melting of internal ice, and it is reasonable to expect similar proportions of north-facing rock glaciers in both inventories. This was observed, suggesting that bias against north and south-facing rock glaciers is not a significant is- sue in our inventory. Some rock glacier movement could also have been hidden by InSAR decorrelation or geometry; however, since these issues were quite uncommon in our velocity maps, they are not likely to have produced widespread inaccuracies or systematic bias in our inventory.

The LOS measurements provided by InSAR underestimate the true 3D velocity of rock glaciers. For rock glaciers with a larger relative component of northward or southward motion, this underestimate is more extreme. In our inventory, North Uintas rock glaciers, which preferentially face north, have significantly lower LOS velocities than South Uintas rock glaciers, which face more equally in all directions. To better account for this issue, we projected LOS velocities along the downslope direction for each rock glacier. Our approach assumes that rock glacier are flowing uniformly along their average downslope direction. However, for rock glaciers that deform in multiple directions, which is common as they can move vertically upwards and travel along multiple azimuths, our projection could have been inaccurate. In particular, for rock glaciers that move with an average downslope direction along the satellite azimuth direction, the projected velocities could be erroneously high. We found that once the LOS velocities are projected downslope, North Uintas rock glaciers have significantly higher velocities than South Uintas rock glaciers.

InSAR unwrapping errors, which are common in areas with high deformation rates and gradients, also likely introduced inaccuracies in our velocity estimates. Several of the fastest rock glaciers move at rates up to $40 \mathrm{~cm} \mathrm{yr}^{-1}$ in $12 \mathrm{~d}$ interferograms but have velocities $<3 \mathrm{~cm} \mathrm{yr}^{-1}$ in the 1 -year pairs used to calculate average velocity. While these discrepancies could be the result of particularly strong seasonal changes in velocity, in longer temporal baseline interferograms, these rock glaciers sometimes had sharp velocity discontinuities consistent with phase jumps caused by unwrapping errors. However, due to the slow velocities of most rock glaciers in the inventory, any unwrapping errors are unlikely to have a large impact on our velocity estimates.

Additional uncertainty in our velocity estimates comes from tropospheric phase delay. We mitigated these errors by (1) estimating velocity using 1 -year pairs, which results in interferograms with a greater signal-to-noise ratio, (2) averaging multiple high-quality interferograms together and using the stack to estimate velocity, (3) implementing a tropospheric phase delay correction, and (4) choosing local stable reference points. However, due to the large areal extent, large altitudinal range, and highly variable topography of the study region, some non-negligible elements of phase delay remain in the 1-year stacks we used to estimate velocity (Fig. 2). In general, the descending stack suffered slightly more from atmospheric errors. The uncertainty in the InSAR velocities is unlikely to be systematic in nature as areas of positive and negative velocities appear to be randomly distributed at the elevations where rock glaciers occur. Importantly, the clearly 
and coherently moving areas of all active or transitional rock glaciers are moving above this level of uncertainty.

\subsection{Time-dependent rock glacier deformation}

Time series constructed from overlapping sets of interferograms provide insight into how rock glacier velocity varies over three superimposed timescales: (1) seasonal, (2) yearly, and (3) multi-year. Over the 4 years that we measured displacement, the Grayling Lake, Whiterocks River, and Rockflour Lake rock glaciers displayed continuous motion with no multi-year trend (Fig. 8). It is likely that this observation period was too small to capture possible long-term trends in rock glacier motion, as has been well-documented in the Alps and other regions (Delaloye et al., 2010; Kääb et al., 2007; Kaufmann and Ladstädter, 2007; Roer et al., 2005; Vonder Muehll et al., 2007; Eriksen et al., 2018; Necsoiu et al., 2016).

On the other hand, Uinta rock glaciers do exhibit a significant seasonal velocity pattern. The three representative rock glaciers moved at an average rate of $4.42 \mathrm{~cm} \mathrm{yr}^{-1}$ during the snow-free period from July to October; the rest of the year, they moved at a rate of $0.86 \mathrm{~cm} \mathrm{yr}^{-1}$. This seasonal rhythm illustrates that Uinta rock glaciers are responsive to the shortterm changes in conditions, such as snowmelt.

Examining velocities of individual rock glaciers over time clarifies how they respond to changes in meltwater delivery. For example, the Rockflour Lake rock glacier moved only $0.11 \mathrm{~cm}$ in the LOS direction from the winter of 2017/18 to the spring of 2019. While near-zero velocities occurred sporadically for multiple rock glaciers during the snow-covered winter months, the absence of any meaningful acceleration of this rock glacier during the following spring, summer, fall, and winter is unique in our dataset. Spring and summer acceleration in rock glaciers is understood to depend on meltwater and precipitation infiltration to the rock glacier shear zone, increasing pore pressure and decreasing the overall material strength (Wirz et al., 2016; Kenner et al., 2017; Cicoira et al., 2019; Fey and Krainer, 2020). During the winter of 2017/18, snow water equivalent (SWE) at the Chepeta SNOTEL station, close to the Rockflour Lake rock glacier, was low, and air temperatures were similar to other winters. This correspondence suggests that spring acceleration of Uinta rock glaciers is controlled by snowmelt and that inadequate meltwater infiltration during the spring and summer may cause a rock glacier to effectively "skip" the summer portion of its seasonal cycle. Reduced spring infiltration of liquid water to the shear zone of the Rockflour Lake rock glacier could explain how even as air and ground temperature rose, this feature did not move a measurable distance during the summer and fall of 2018.

Both the Grayling Lake and Whiterocks River rock glaciers accelerated normally during the warmer months of 2018. The Grayling Lake rock glacier is close to the Five Points Lake SNOTEL station, which received around $15 \mathrm{~cm}$ more SWE than the Chepeta SNOTEL station during the winter of 2017/18 and had a more robust snowmelt event in the spring. Thus, this rock glacier likely received the requisite amount of meltwater infiltration for normal acceleration. The Whiterocks River rock glacier is closest to the Chepeta SNOTEL station but is $260 \mathrm{~m}$ higher in elevation. Snowpack at the Whiterocks River rock glacier may have been much larger than at the Chepeta station, which could explain its normal spring acceleration. Alternatively, the Whiterocks River rock glacier could require less water to accelerate in the spring.

Collectively, these results illustrate that Uinta rock glaciers are sensitive to changes in climatic conditions, though individual rock glaciers did not respond uniformly to reduced snowmelt in 2018. Our data are not sufficient to determine whether dissimilar responses were caused by local variations in climate that were not reflected in our regional weather data or by individual rock glaciers responding differently to similar climate events. Time series analysis of additional rock glaciers with high-resolution weather data would aid our understanding of Uinta rock glaciers' response to climate events.

\subsection{Rock glaciers and climate change}

Our results suggest that Uinta rock glaciers are vulnerable to loss of internal ice due to climate change. Currently, $90.7 \%$ of these features are found at MAATs above $-1.5^{\circ} \mathrm{C}$. If warming continues as predicted, all of these rock glaciers will have MAATs at or above $0{ }^{\circ} \mathrm{C}$ in the next 10 years (IPCC, 2018). Because the PRISM temperature data used here are effectively 25 years old, they underestimate current MAATs. PRISM 30-year normals provide a MAAT of $0.11^{\circ} \mathrm{C}$ at the Chepeta SNOTEL and $0.52{ }^{\circ} \mathrm{C}$ at the Five Points Lake SNOTEL, but measured MAAT over the past 5 years at these stations has been warmer, at 1.35 and $0.97^{\circ} \mathrm{C}$, respectively. It is likely that almost all Uinta rock glaciers are experiencing significant ice loss in response to rising temperatures. The presence of 199 inactive rock glaciers supports this claim.

Further support for this conclusion comes from the slow velocities of Uinta rock glaciers. In the European Alps and Norway, warming temperatures have been associated with rock glacier acceleration and destabilization, as newly established channels in permafrost direct meltwater and rain to the shear zone (Delaloye et al., 2010; Kääb et al., 2007; Kaufmann and Ladstädter, 2007; Roer et al., 2005; Vonder Muehll et al., 2007; Eriksen et al., 2018). However, in these locales, precipitation is generally increasing, and rainfall is replacing snowfall. In contrast, at the Five Points Lake and Chepeta SNOTEL stations in the Uintas, MAP has decreased over the past 40 years, and rainfall has decreased at a faster rate than snowfall (Fig. 10g and h). In the Uintas, and much of the western United States, climate change is characterized by increasing aridity (Gutzler and Robbins, 2011). This aridity could explain the slow velocities of Uinta rock glaciers as 
Five Points Lake SNOTEL

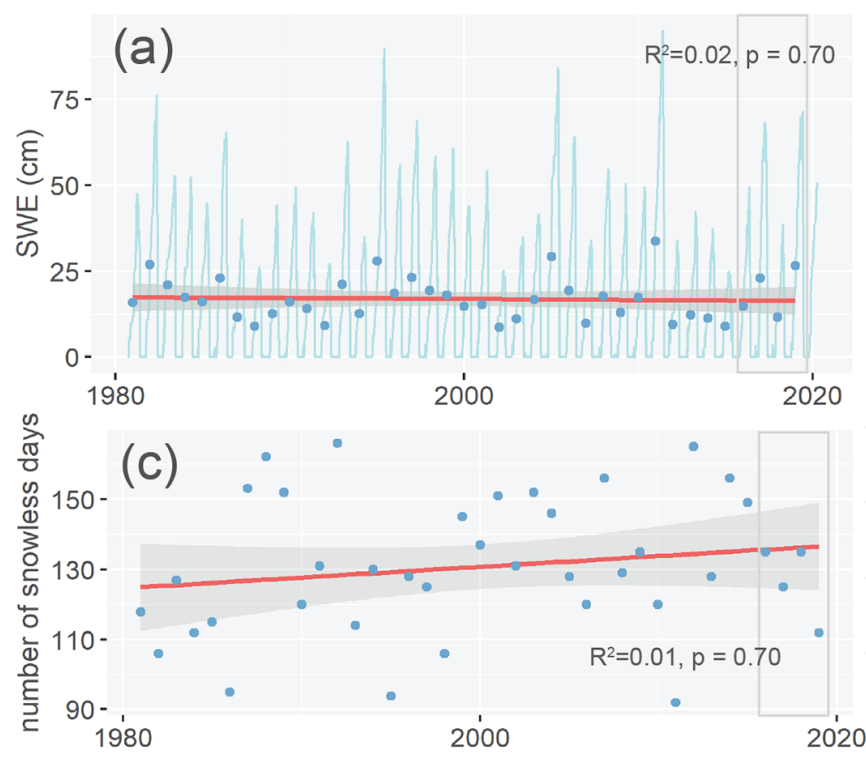

\section{Chepeta SNOTEL}

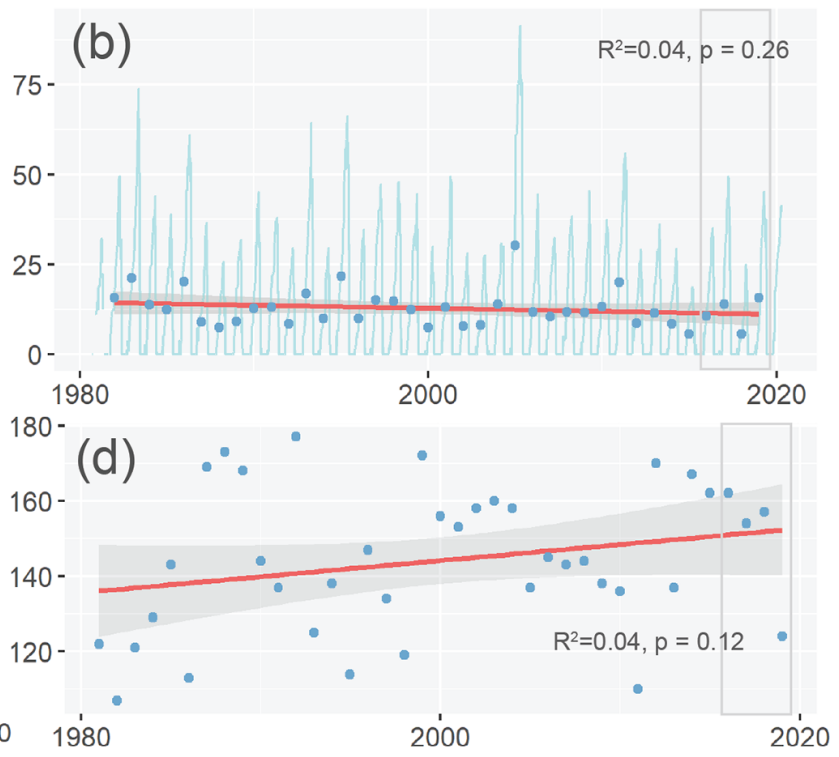

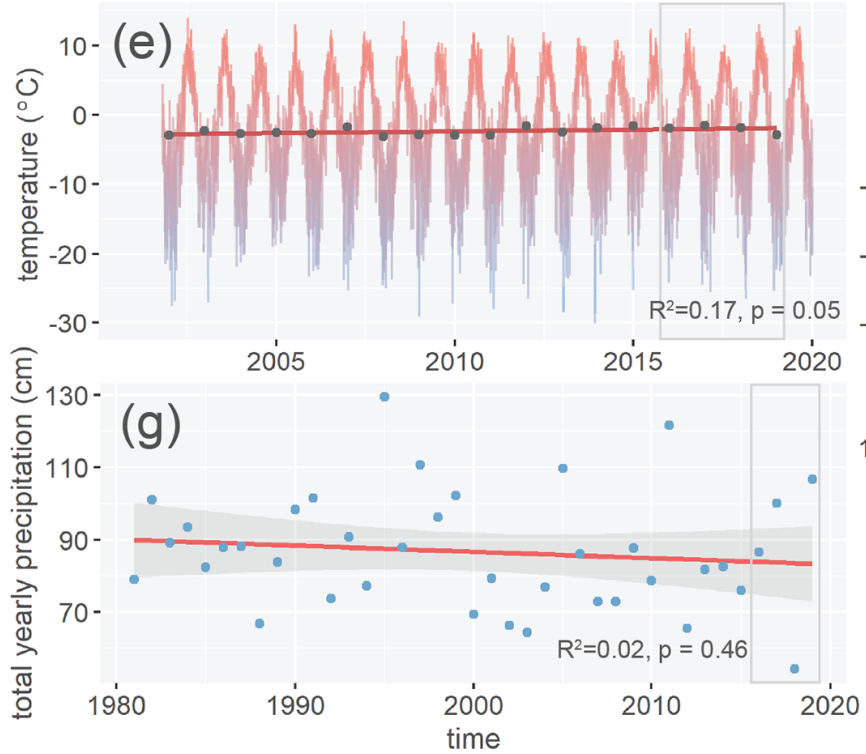

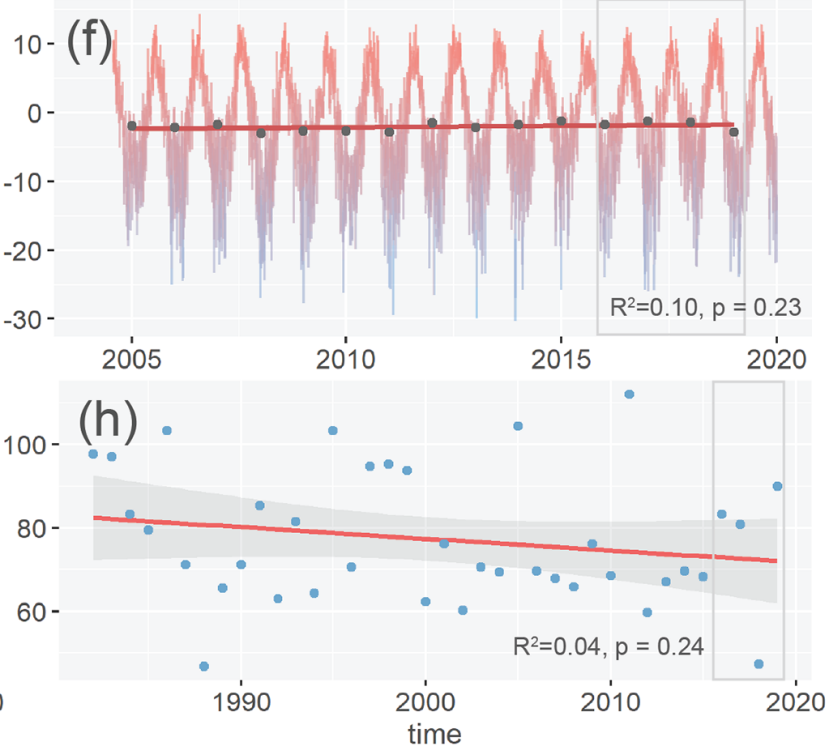

Figure 10. Climate over the past 40 years at the Five Points Lake SNOTEL (left) and Chepeta (right) SNOTEL stations. (a, b) Snow water equivalent (SWE). The light blue line is daily SWE. The dark blue points are mean annual SWE. (c, d) Number of days with no snow cover. Blue points represent number of days per year when SWE is 0. (e, f) Temperature over time. Blue to red regions represent daily temperature. Grey points are mean annual air temperature. $(\mathbf{g}, \mathbf{h})$. Mean annual precipitation over time. Blue points represent mean annual precipitation. For all, red lines are linear trend lines, and gray regions around lines are $95 \%$ confidence intervals. Gray boxes represent the study period.

(1) reduced winter snowpack means that spring accelerations are less extreme (Fig. 10a and b), and (2) reduced rainfall results in less heat pumped into the rock glacier interior and less water in the shear zone, further reducing rock glacier velocity. Thus, rock glacier degradation in the Uintas is unlikely to manifest as destabilization and acceleration. Instead, degrading permafrost may manifest as progressively slower rock glacier velocities and eventual inactivation as decreasing ice content, increasing frictional interactions from lib- erated debris, and decreased shear stress as a result of reduced rock glacier thickness serve to slow the rock glacier. These processes can explain the slow velocities of Uinta rock glaciers and may indicate that these features are not as vulnerable to rapid ice loss as those in parts of the world with increasing precipitation and rain. Uinta rock glaciers may, therefore, serve as a water resource for a longer period of time relative to their ice content and are unlikely to undergo hazardous destabilization (Marcer et al., 2021). 


\subsection{Implications for hydrology}

Following calculations in Munroe (2018), which assume a rock glacier and talus thickness of $10 \mathrm{~m}$, an average porosity of $30 \%$, and $25 \%$ ice saturation of pore space, active and transitional rock glaciers mapped in this study contain about $1.82 \times 10^{7} \mathrm{~m}^{3}$ of water, equal to about $1 \%$ of annual runoff from the Uintas (Jeppson, 1968). Other works have used less conservative numbers for ice content of rock glaciers. For example, Janke et al. (2017) estimated ice content of active rock glaciers in the semiarid Aconcagua River Basin of Chile to be between $25 \%$ and $44.9 \%$, and Jones et al. (2018b) estimated ice content of active rock glaciers in the Nepalese Himalayas to be between $40 \%$ and $60 \%$. Using these estimates, active and transitional rock glaciers in the Uintas could store $6.1 \times 10^{7}-1.46 \times 10^{8} \mathrm{~m}^{3}$ of water, up to $8.10 \%$ of the annual runoff from these mountains. These calculations illustrate that rock glaciers in the Uintas could store and seasonally release non-trivial quantities of water. However, if Uinta rock glaciers have experienced significant loss of internal ice due to climate change, water storage will be on the lower end of this spectrum.

While the magnitude of this release may be small compared to the total runoff from the Uintas, it likely makes up a much larger portion of runoff in the high-elevation areas. The timing of meltwater release is also likely to be important. Uinta rock glaciers melt at the fastest rate in the summer, when temperatures are highest, and rainfall delivers liquid water to the interior of the rock glacier. In the late summer, when precipitation in the Uintas is scarce, rock glacier meltwater probably contributes a larger proportion of total streamflow (MacDonald and Tingstad, 2007). As noted by Munroe (2018), if rock glaciers provide a significant input to late summer base flow, climate change will likely produce a short-term increase in water availability as rock glaciers melt at increased rates, followed by a long-term decrease in water availability (Clow et al., 2003).

\section{Conclusions}

In this study an inventory of 205 active and transitional rock glaciers in the Uinta Mountains, Utah, was constructed using InSAR from the Copernicus Sentinel-1 satellites, Google Earth imagery, and topographic data. Rock glaciers in the Uinta Mountains have an average area of 11.9 ha, commonly face north or northeast, and are found within a narrow elevation band ranging from 3100 and 3500 (average of $3290 \mathrm{~m}$ ), corresponding to a MAAT of 0.5 to $-2.0^{\circ} \mathrm{C}$ (average of $-0.15^{\circ} \mathrm{C}$ ). Rock glacier location is controlled by a combination of mountain geometry and air temperature. InSARderived downslope rock glacier velocities are between 0.35 and $6.03 \mathrm{~cm} \mathrm{yr}^{-1}$, with an average of $1.92 \mathrm{~cm} \mathrm{yr}^{-1}$, and are not correlated with variables including elevation, area, aspect, slope, or morphology. Time series analysis of three rock glaciers revealed a seasonal rhythm in LOS velocities, with an average of $4.42 \mathrm{~cm} \mathrm{yr}^{-1}$ during the snow-free late summer and $0.86 \mathrm{~cm} \mathrm{yr}^{-1}$ during the rest of the year. The Rockflour Lake rock glacier did not accelerate during 2018 because of minimal spring snowmelt following a winter with abnormally low snowfall. We speculate that generally slow rock glacier velocities throughout the Uintas may be related to reduced ice content and increasing aridity caused by ongoing climate change. We estimate that rock glaciers in the Uintas store a volume of water equivalent to $1 \%-9 \%$ of annual runoff from these mountains. During the late summer, when precipitation over the Uintas is comparatively low, rock glacier melting may provide an important addition to stream base flow, particularly at high elevations. As climate change continues, the rock glacier contribution to late summer runoff is expected to increase as rock glaciers melt, before decreasing in the long term as Uinta rock glaciers become relict.

\section{Appendix A}

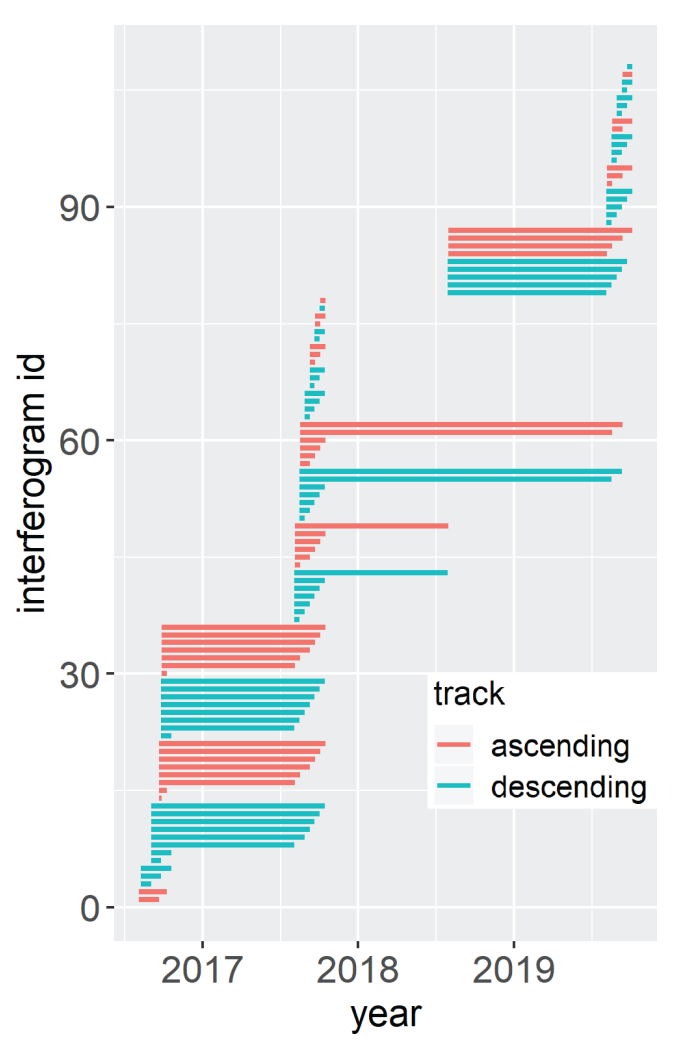

Figure A1. Temporal distribution of interferograms. Interferograms were generated using Sentinel 1 IW SLC (single look complex) scenes. Interferogram pairs were chosen based on snow-free periods. Red and blue lines represent ascending and descending interferograms, respectively. 
Table A1. Track, date, and time span of all interferograms generated. Pairs that were averaged to create the ascending and descending 1-year stacks used to estimate LOS velocities of rock glaciers are bolded.

\begin{tabular}{|c|c|c|c|c|}
\hline Number & Track & $\begin{array}{r}\text { Primary acquisition } \\
\text { date (yyyymmdd) }\end{array}$ & $\begin{array}{r}\text { Secondary acquisition } \\
\text { date (yyyymmdd) }\end{array}$ & $\begin{array}{r}\text { Time span } \\
\text { (days) }\end{array}$ \\
\hline 1 & T122 ascending & 20160804 & 20160921 & 48 \\
\hline 2 & T122 ascending & 20160921 & 20160927 & 6 \\
\hline 3 & T122 ascending & 20160804 & 20161009 & 66 \\
\hline 4 & T122 ascending & 20160921 & 20161009 & 18 \\
\hline 5 & T122 ascending & 20160927 & 20161009 & 12 \\
\hline 6 & T122 ascending & 20160921 & 20170805 & 318 \\
\hline 7 & T122 ascending & 20160927 & 20170805 & 312 \\
\hline 8 & T122 ascending & 20160921 & 20170817 & 330 \\
\hline 9 & T122 ascending & 20160927 & 20170817 & 324 \\
\hline 10 & T122 ascending & 20170805 & 20170817 & 12 \\
\hline 11 & T122 ascending & 20160921 & 20170910 & 354 \\
\hline 12 & T122 ascending & 20160927 & 20170910 & 348 \\
\hline 13 & T122 ascending & 20170805 & 20170910 & 36 \\
\hline 14 & T122 ascending & 20170817 & 20170910 & 24 \\
\hline 15 & T122 ascending & 20160921 & 20170922 & 366 \\
\hline 16 & T122 ascending & 20160927 & 20170922 & 360 \\
\hline 17 & T122 ascending & 20170805 & 20170922 & 48 \\
\hline 18 & T122 ascending & 20170817 & 20170922 & 36 \\
\hline 19 & T122 ascending & 20170910 & 20170922 & 12 \\
\hline 20 & T122 ascending & 20160921 & 20171004 & 378 \\
\hline 21 & T122 ascending & 20160927 & 20171004 & 372 \\
\hline 22 & T122 ascending & 20170805 & 20171004 & 60 \\
\hline 23 & T122 ascending & 20170817 & 20171004 & 48 \\
\hline 24 & $\mathrm{~T} 122$ ascending & 20170910 & 20171004 & 24 \\
\hline 25 & T122 ascending & 20170922 & 20171004 & 12 \\
\hline 26 & T122 ascending & 20160921 & 20171016 & 390 \\
\hline 27 & T122 ascending & 20160927 & 20171016 & 384 \\
\hline 28 & T122 ascending & 20170805 & 20171016 & 72 \\
\hline 29 & T122 ascending & 20170817 & 20171016 & 60 \\
\hline 30 & T122 ascending & 20170910 & 20171016 & 36 \\
\hline 31 & T122 ascending & 20170922 & 20171016 & 24 \\
\hline 32 & T122 ascending & 20171004 & 20171016 & 12 \\
\hline 33 & T122 ascending & 20170805 & 20180731 & 360 \\
\hline 34 & T122 ascending & 20180731 & 20190807 & 372 \\
\hline 35 & T122 ascending & 20170817 & 20190819 & 732 \\
\hline 36 & T122 ascending & 20180731 & 20190819 & 384 \\
\hline 37 & T122 ascending & 20190807 & 20190819 & 12 \\
\hline 38 & T122 ascending & 20170817 & 20190912 & 756 \\
\hline 39 & T122 ascending & 20180731 & 20190912 & 408 \\
\hline 40 & T122 ascending & 20190807 & 20190912 & 36 \\
\hline 41 & T122 ascending & 20190819 & 20190912 & 24 \\
\hline 42 & T122 ascending & 20180731 & 20191006 & 432 \\
\hline 43 & T122 ascending & 20190807 & 20191006 & 60 \\
\hline 44 & T122 ascending & 20190819 & 20191006 & 48 \\
\hline 45 & T122 ascending & 20190912 & 20191006 & 24 \\
\hline 46 & T27 descending & 20160809 & 20160902 & 24 \\
\hline 47 & T27 descending & 20160809 & 20160926 & 48 \\
\hline 48 & T27 descending & 20160902 & 20160926 & 24 \\
\hline 49 & T27 descending & 20160809 & 20161020 & 72 \\
\hline 50 & T27 descending & 20160902 & 20161020 & 48 \\
\hline 51 & T27 descending & 20160926 & 20161020 & 24 \\
\hline 52 & T27 descending & 20160902 & 20170804 & 336 \\
\hline 53 & T27 descending & 20160926 & 20170804 & 312 \\
\hline
\end{tabular}


Table A1. Continued.

\begin{tabular}{|c|c|c|c|c|}
\hline Number & Track & $\begin{array}{r}\text { Primary acquisition } \\
\text { date (yyyymmdd) }\end{array}$ & $\begin{array}{r}\text { Secondary acquisition } \\
\text { date (yyyymmdd) }\end{array}$ & $\begin{array}{r}\text { Time span } \\
\text { (days) }\end{array}$ \\
\hline 54 & T27 descending & 20160926 & 20170816 & 324 \\
\hline 55 & T27 descending & 20170804 & 20170816 & 12 \\
\hline 56 & T27 descending & 20160902 & 20170828 & 360 \\
\hline 57 & T27 descending & 20160926 & 20170828 & 336 \\
\hline 58 & T27 descending & 20170804 & 20170828 & 24 \\
\hline 59 & T27 descending & 20170816 & 20170828 & 12 \\
\hline 60 & T27 descending & 20160902 & 20170909 & 372 \\
\hline 61 & T27 descending & 20160926 & 20170909 & 348 \\
\hline 62 & T27 descending & 20170804 & 20170909 & 36 \\
\hline 63 & T27 descending & 20170816 & 20170909 & 24 \\
\hline 64 & T27 descending & 20170828 & 20170909 & 12 \\
\hline 65 & T27 descending & 20160902 & 20170921 & 384 \\
\hline 66 & T27 descending & 20160926 & 20170921 & 360 \\
\hline 67 & T27 descending & 20170804 & 20170921 & 48 \\
\hline 68 & T27 descending & 20170816 & 20170921 & 36 \\
\hline 69 & T27 descending & 20170828 & 20170921 & 24 \\
\hline 70 & T27 descending & 20170909 & 20170921 & 12 \\
\hline 71 & T27 descending & 20160902 & 20171003 & 396 \\
\hline 72 & T27 descending & 20160926 & 20171003 & 372 \\
\hline 73 & T27 descending & 20170804 & 20171003 & 60 \\
\hline 74 & T27 descending & 20170816 & 20171003 & 48 \\
\hline 75 & T27 descending & 20170828 & 20171003 & 36 \\
\hline 76 & T27 descending & 20170909 & 20171003 & 24 \\
\hline 77 & T27 descending & 20170921 & 20171003 & 12 \\
\hline 78 & T27 descending & 20160902 & 20171015 & 408 \\
\hline 79 & T27 descending & 20160926 & 20171015 & 384 \\
\hline 80 & T27 descending & 20170804 & 20171015 & 72 \\
\hline 81 & T27 descending & 20170816 & 20171015 & 60 \\
\hline 82 & T27 descending & 20170828 & 20171015 & 48 \\
\hline 83 & T27 descending & 20170909 & 20171015 & 36 \\
\hline 84 & T27 descending & 20170921 & 20171015 & 24 \\
\hline 85 & T27 descending & 20171003 & 20171015 & 12 \\
\hline 86 & T27 descending & 20170804 & 20180730 & 360 \\
\hline 87 & T27 descending & 20180730 & 20190806 & 372 \\
\hline 88 & T27 descending & 20170816 & 20190818 & 732 \\
\hline 89 & T27 descending & 20180730 & 20190818 & 384 \\
\hline 90 & T27 descending & 20190806 & 20190818 & 12 \\
\hline 91 & T27 descending & 20180730 & 20190830 & 396 \\
\hline 92 & T27 descending & 20190806 & 20190830 & 24 \\
\hline 93 & T27 descending & 20190818 & 20190830 & 12 \\
\hline 94 & T27 descending & 20170816 & 20190911 & 756 \\
\hline 95 & T27 descending & 20180730 & 20190911 & 408 \\
\hline 96 & T27 descending & 20190806 & 20190911 & 36 \\
\hline 97 & T27 descending & 20190818 & 20190911 & 24 \\
\hline 98 & T27 descending & 20190830 & 20190911 & 12 \\
\hline 99 & T27 descending & 20180730 & 20190923 & 420 \\
\hline 100 & T27 descending & 20190806 & 20190923 & 48 \\
\hline 101 & T27 descending & 20190818 & 20190923 & 36 \\
\hline 102 & T27 descending & 20190830 & 20190923 & 24 \\
\hline 103 & T27 descending & 20190911 & 20190923 & 12 \\
\hline 104 & T27 descending & 20190806 & 20191005 & 60 \\
\hline 105 & T27 descending & 20190818 & 20191005 & 48 \\
\hline 106 & T27 descending & 20190830 & 20191005 & 36 \\
\hline 107 & T27 descending & 20190911 & 20191005 & 24 \\
\hline 108 & T27 descending & 20190923 & 20191005 & 12 \\
\hline
\end{tabular}



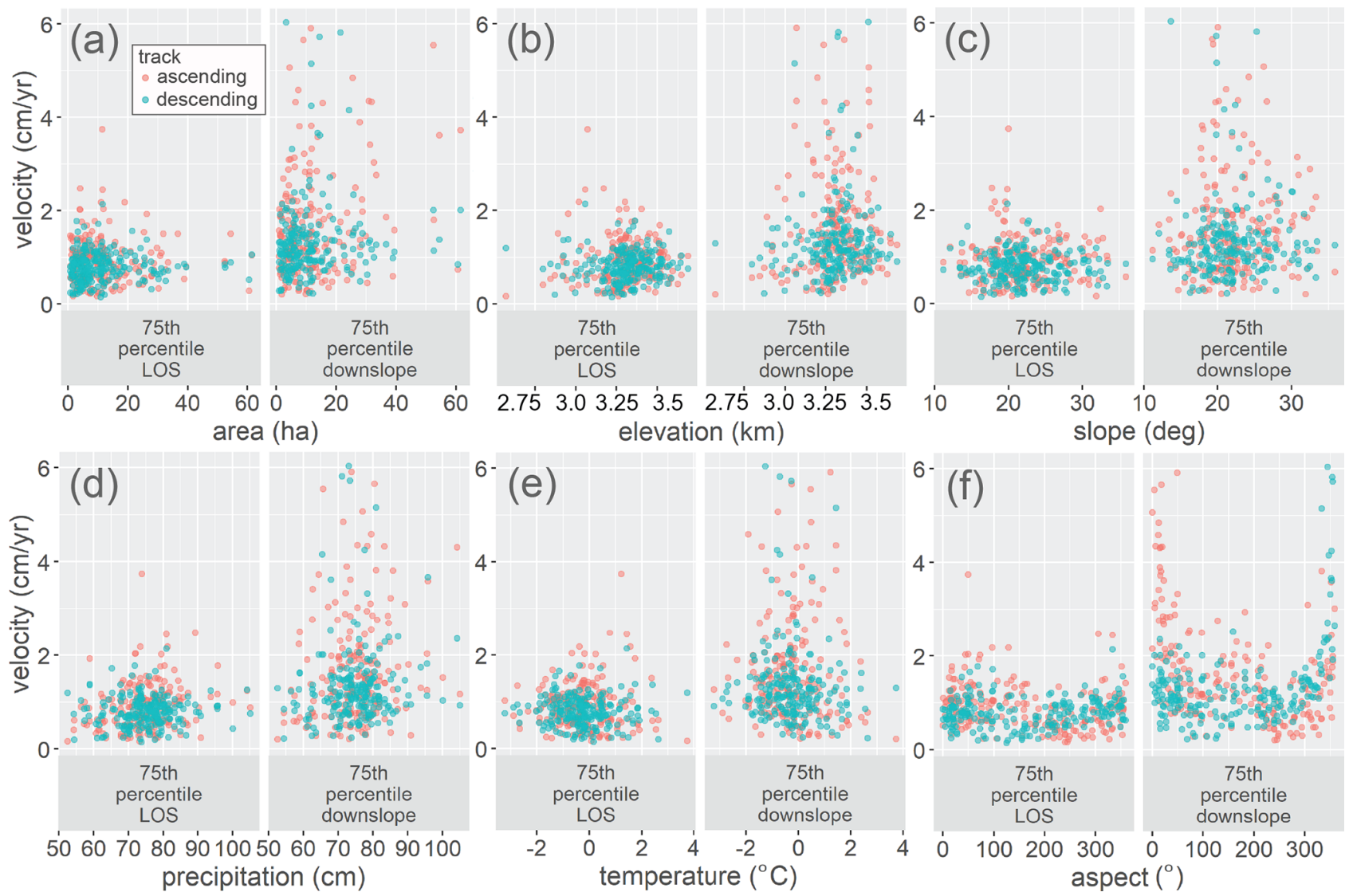

Figure A2. Rock glacier velocity plotted against physical variables and climate envelope. In all plots, velocity is the absolute value of 75 th percentile LOS velocity on the left and 75th percentile downslope velocity on the right, compared to (a) rock glacier area, (b) rock glacier elevation, (c) rock glacier slope, (d) rock glacier mean annual precipitation, (e) rock glacier mean annual air temperature, and (f) rock glacier aspect. Two velocity values are presented for each rock glacier: one is derived from the ascending 1-year stack (red) and one from the descending 1-year stack (blue). Temperature and precipitation data are from PRISM, and $n=205$.

Data availability. The research data used in this study are freely available online. SAR scenes used to generate interferograms are available on the Alaska Satellite Foundation Vertex website (https: //vertex.daac.asf.alaska.edu/, last access: 18 August 2021). Corresponding POD Precise Orbit Ephemerides data can be found on the ESA website (https://scihub.copernicus.eu/gnss/\#/home, last access: 18 August 2021). The $30 \mathrm{~m}$ SRTM DEM is available from the USGS Earth Explorer website (https://earthexplorer.usgs.gov/, last access: 18 August 2021), and the $10 \mathrm{~m}$ USGS 3DEP DEM is available from the USGS National Map website (https://viewer. nationalmap.gov/basic/, last access: 18 August 2021). PRISM data can be downloaded from the PRISM website (PRISM Climate Group, 2004, https://prism.oregonstate.edu/, last access: $18 \mathrm{Au}$ gust 2021). SNOTEL data are available on the Natural Resources Conservation Service website (https://www.nrcs.usda.gov/ wps/portal/wcc/home/, last access: 18 August 2021).

Author contributions. JSM and ALH devised the idea for the project. ALH and GB designed the methodology. GB carried out the methodology with guidance from ALH. GB analyzed the data.
GB made the figures with advice from JSM and ALH. GB wrote the manuscript with significant input from JSM and ALH.

Competing interests. The authors declare that they have no conflict of interest.

Disclaimer. Publisher's note: Copernicus Publications remains neutral with regard to jurisdictional claims in published maps and institutional affiliations.

Acknowledgements. Part of this research was carried out at the Jet Propulsion Laboratory, California Institute of Technology, under a contract with the National Aeronautics and Space Administration (80NM0018D0004). We would like to thank the scientists at the Jet Propulsion Laboratory for generously providing their insight to George Brencher during a research visit. Funding to support the JPL visit was awarded to George Brencher by Middlebury College's Senior Research Project Supplement. 
Financial support. This research has been supported by the National Science Foundation, Directorate for Geosciences (grant no. EAR-1935200).

Review statement. This paper was edited by Francesca Pellicciotti and reviewed by three anonymous referees.

\section{References}

Arenson, L., Hoelzle, M., and Springman, S.: Borehole deformation measurements and internal structure of some rock glaciers in Switzerland, Permafrost. Periglac., 13, 117-135, https://doi.org/10.1002/ppp.414, 2002.

Azócar, G. and Brenning, A.: Hydrological and geomorphological significance of rock glaciers in the dry Andes, Chile (27-33 S), Permafrost. Periglac., 21, 42-53, https://doi.org/10.1002/ppp.669, 2010.

Barboux, C., Delaloye, R., and Lambiel, C.: Inventorying slope movements in an Alpine environment using DInSAR, Earth Surf. Proc. Land., 39, 2087-2099, https://doi.org/10.1002/esp.3603, 2014.

Barnett, T. P. and Pierce, D. W.: When will Lake Mead go dry?, Water Resour. Res., 44, W03201, https://doi.org/10.1029/2007WR006704, 2008.

Barsch, D.: Rock-glaciers: Indicators for the present and former geoecology of high mountain environments, Springer, Berlin, Heidelberg, Germany, 1996.

Bartholomew, I., Nienow, P., Mair, D., Hubbard, A., King, M. A., and Sole, A.: Seasonal evolution of subglacial drainage and acceleration in a Greenland outlet glacier, Nat. Geosci., 3, 408-411, https://doi.org/10.1038/ngeo863, 2010.

Bayer, B., Simoni, A., Mulas, M., Corsini, A., and Schmidt, D.: Deformation responses of slow moving landslides to seasonal rainfall in the Northern Apennines, measured by InSAR, Geomorphology, 308, 293-306, https://doi.org/10.1016/j.geomorph.2018.02.020, 2018.

Bekaert, D. P. S., Walters, R. J., Wright, T. J., Hooper, A. J., and Parker, D. J.: Statistical comparison of InSAR tropospheric correction techniques, Remote Sens. Environ., 170, 4047, https://doi.org/10.1016/j.rse.2015.08.035, 2015.

Berardino, P., Fornaro, G., Lanari, R., and Sansosti, E.: A new algorithm for surface deformation monitoring based on small baseline differential SAR interferograms, IEEE T. Geosci. Remote, 40, 2375-2383, https://doi.org/10.1109/TGRS.2002.803792, 2002.

Boeckli, L., Brenning, A., Gruber, S., and Noetzli, J.: Permafrost distribution in the European Alps: calculation and evaluation of an index map and summary statistics, The Cryosphere, 6, 807820, https://doi.org/10.5194/tc-6-807-2012, 2012.

Bradley, W. H.: Geomorphology of the North Flank of the Uinta Mountains, US Geological Survey, US Government Printing Office, Washington DC, USA, https://doi.org/10.3133/pp185I, 1936.

Brardinoni, F., Scotti, R., Sailer, R., and Mair, V.: Evaluating sources of uncertainty and variability in rock glacier inventories, Earth Surf. Proc. Land., 44, 2450-2466, https://doi.org/10.1002/esp.4674, 2019.
Bürgmann, R.: The Geophysics, Geology and Mechanics of Slow Fault Slip, Earth Planet. Sc. Lett., 495, 112-134, https://doi.org/10.1016/j.epsl.2018.04.062, 2018.

Chen, C. W. and Zebker, H. A.: Phase unwrapping for large SAR interferograms: Statistical segmentation and generalized network models, IEEE T. Geosci. Remote, 40, 1709-1719, https://doi.org/10.1109/TGRS.2002.802453, 2002.

Cicoira, A., Beutel, J., Faillettaz, J., and Vieli, A.: Water controls the seasonal rhythm of rock glacier flow, Earth Planet. Sc. Lett., 528, 115844, https://doi.org/10.1016/j.epsl.2019.115844, 2019.

Clow, D. W., Schrott, L., Webb, R., Campbell, D. H., Torizzo, A., and Dornblaser, M.: Ground water occurrence and contributions to streamflow in an alpine catchment, Colorado Front Range, Groundwater, 41, 937-950, https://doi.org/10.1111/j.1745-6584.2003.tb02436.x, 2003.

Degenhardt Jr., J. J.: Development of tongue-shaped and multilobate rock glaciers in alpine environments-Interpretations from ground penetrating radar surveys, Geomorphology, 109, 94-107, https://doi.org/10.1016/j.geomorph.2009.02.020, 2009.

Dehler, C. M., Porter, S. M., De Grey, L. D., Sprinkel, D. A., and Brehm, A.: The Neoproterozoic Uinta Mountain Group revisited; a synthesis of recent work on the Red Pine Shale and related undivided clastic strata, northeastern Utah, U.S.A., in: Proterozoic Geology of Western North America and Siberia, edited by: Link, P. K. and Lewis, R. S., Society for Sedimentary Geology, Tulsa, USA, 151-166, https://doi.org/10.2110/pec.07.86.0151, 2007.

Delaloye, R., Lambiel, C., and Gärtner-Roer, I.: Overview of rock glacier kinematics research in the Swiss Alps, Geogr. Helv., 65, 135-145, https://doi.org/10.5194/gh-65-135-2010, 2010.

Eriksen, H. Ø., Rouyet, L., Lauknes, T. R., Berthling, I., Isaksen, K., Hindberg, H., Larsen, Y., and Corner, G. D.: Recent acceleration of a rock glacier complex, Adjet, Norway, documented by 62 years of remote sensing observations, Geophys. Res. Lett., 45, 8314-8323, https://doi.org/10.1029/2018GL077605, 2018.

Falaschi, D., Castro, M., Masiokas, M., Tadono, T., and Ahumada, A. L.: Rock glacier inventory of the Valles Calchaquíes region $(\sim 25 \mathrm{~S})$, Salta, Argentina, derived from ALOS data, Permafrost. Periglac., 25, 69-75, https://doi.org/10.1002/ppp.1801, 2014.

Fey, C. and Krainer, K.: Analyses of UAV and GNSS based flow velocity variations of the rock glacier Lazaun (Ötztal Alps, South Tyrol, Italy), Geomorphology, 365, 107261, https://doi.org/10.1016/j.geomorph.2020.107261, 2020.

Frauenfelder, R. and Kääb, A.: Towards a palaeoclimatic model of rock-glacier formation in the Swiss Alps, Ann. Glaciol., 31, 281286, https://doi.org/10.3189/172756400781820264, 2000.

Gutzler, D. S. and Robbins, T. O.: Climate variability and projected change in the western United States: regional downscaling and drought statistics, Clim. Dynam., 37, 835-849, https://doi.org/10.1007/s00382-010-0838-7, 2011.

Haeberli, W.: Creep of mountain permafrost: internal structure and flow of alpine rock glaciers, Mitteilungen der Versuchsanstalt fur Wasserbau, Hydrologie und Glaziologie an der ETH Zurich, 77, 1985.

Haeberli, W., Hallet, B., Arenson, L., Elconin, R., Humlum, O., Kääb, A., Kaufmann, V., Ladanyi, B., Matsuoka, N., Springman, S., and Mühll, D. V.: Permafrost creep and 
rock glacier dynamics, Permafrost. Periglac., 17, 189-214, https://doi.org/10.1002/ppp.561, 2006.

Hales, T. C. and Roering, J. J.: Climatic controls on frost cracking and implications for the evolution of bedrock landscapes, J. Geophys. Res.-Earth, 112, F02033, https://doi.org/10.1029/2006JF000616, 2007.

Handwerger, A. L., Fielding, E. J., Huang, M. H., Bennett, G. L., Liang, C., and Schulz, W. H.: Widespread initiation, reactivation, and acceleration of landslides in the northern California Coast Ranges due to extreme rainfall, J. Geophys. Res.-Earth, 124, 1782-1797, https://doi.org/10.1029/2019JF005035, 2019.

Hinzman, L. D., Goering, D. J., and Kane, D. L.: A distributed thermal model for calculating soil temperature profiles and depth of thaw in permafrost regions, J. Geophys. Res.-Atmos., 103, 28975-28991, https://doi.org/10.1029/98JD01731, 1998.

Hoelzle, M. and Haeberli, W.: Simulating the effects of mean annual air-temperature changes on permafrost distribution and glacier size: an example from the Upper Engadin, Swiss Alps, Ann. Glaciol., 21, 399-405, https://doi.org/10.3189/S026030550001613X, 1995.

Ikeda, A., Matsuoka, N., and Kääb, A.: Fast deformation of perennially frozen debris in a warm rock glacier in the Swiss Alps: An effect of liquid water, J. Geophys. Res.-Earth, 113, F01021, https://doi.org/10.1029/2007JF000859, 2008.

IPA Action Group Rock Glacier Inventories and Kinematics: Baseline Concepts Version 4.1. Université de Fribourg Geomorphology Research Group, available at: https://www.unifr.ch/geo/ geomorphology/en/research/ipa-action-group-rock-glacier/ (last access: 18 August 2021), 2020.

IPCC: Summary for Policymakers, in: Global Warming of $1.5^{\circ} \mathrm{C}$. An IPCC Special Report on the impacts of global warming of $1.5^{\circ} \mathrm{C}$ above pre-industrial levels and related global greenhouse gas emission pathways, in the context of strengthening the global response to the threat of climate change, sustainable development, and efforts to eradicate poverty, edited by: MassonDelmotte, V., Zhai, P., Pörtner, H. O., Roberts, D., Skea, J., Shukla, P. R., Pirani, A., Moufouma-Okia, W., Péan, C., Pidcock, R., Connors, S., Matthews, J. B. R., Chen, Y., Zhou, X., Gomis, M. I., Lonnoy, E., Maycock, T., Tignor, M., and Waterfield, T., World Meteorological Organization, Geneva, Switzerland, 32 pp., 2018.

Iverson, N. R.: Shear resistance and continuity of subglacial till: hydrology rules, J. Glaciol., 56, 1104-1114, https://doi.org/10.3189/002214311796406220, 2010.

Janke, J. R.: Long-term flow measurements (1961-2002) of the Arapaho, Taylor, and Fair rock glaciers, Front Range, Colorado, Phys. Geogr., 26, 313-336, https://doi.org/10.2747/02723646.26.4.313, 2005.

Janke, J. R.: Colorado Front Range rock glaciers: distribution and topographic characteristics, Arct. Antarct. Alp. Res., 39, 74-83, https://doi.org/10.1657/15230430(2007)39[74:CFRRGD]2.0.CO;2, 2007.

Janke, J. R., Ng, S., and Bellisario, A.: An inventory and estimate of water stored in firn fields, glaciers, debriscovered glaciers, and rock glaciers in the Aconcagua River Basin, Chile, Geomorphology, 296, 142-152, https://doi.org/10.1016/j.geomorph.2017.09.002, 2017.

Jeppson, R. W.: Hydrologic Atlas of Utah, Utah Water Research Laboratory, Utah State University, Logan, USA, Paper 297, avail- able at: https://digitalcommons.usu.edu/water_rep/297 (last access: 18 August 2021), 1968.

Johnson, B. G., Thackray, G. D., and Van Kirk, R.: The effect of topography, latitude, and lithology on rock glacier distribution in the Lemhi Range, central Idaho, USA, Geomorphology, 91, 38-50, https://doi.org/10.1016/j.geomorph.2007.01.023, 2007.

Jones, D. B., Harrison, S., Anderson, K., and Betts, R. A.: Mountain rock glaciers contain globally significant water stores, Sci. Rep.-UK, 8, 2834, https://doi.org/10.1038/s41598-018-21244-w, 2018a.

Jones, D. B., Harrison, S., Anderson, K., Selley, H. L., Wood, J. L., and Betts, R. A.: The distribution and hydrological significance of rock glaciers in the Nepalese Himalaya, Global Planet. Change, 160, 123-142, https://doi.org/10.1016/j.gloplacha.2017.11.005, 2018b.

Kääb, A., Kaufmann, V., Ladstädter, R., and Eiken, T.: Rock glacier dynamics: implications from high resolution measurements of surface velocity fields, in: Proceedings of the Eighth International Conference on Permafrost, Zurich, Balkema, 501-506, 21-25 July 2003.

Kääb, A., Frauenfelder, R., and Roer, I.: On the response of rockglacier creep to surface temperature increase, Global Planet. Change, 56, 172-187, https://doi.org/10.1016/j.gloplacha.2006.07.005, 2007.

Kääb, A., Strozzi, T., Bolch, T., Caduff, R., Trefall, H., Stoffel, M., and Kokarev, A.: Inventory and changes of rock glacier creep speeds in Ile Alatau and Kungöy Ala-Too, northern Tien Shan, since the 1950s, The Cryosphere, 15, 927-949, https://doi.org/10.5194/tc-15-927-2021, 2021.

Kaufmann, V. and Ladstädter, R.: Mapping of the 3D surface motion field of Doesen rock glacier (Ankogel group, Austria) and its spatio-temporal change (1954-1998) by means of digital photogrammetry, in: International Symposium on High Mountain Remote Sensing Cartography, 14-15 September 2006, Graz, Austria, 127-144, 2007.

Kellerer-Pirklbauer, A., Lieb, G. K., and Kleinferchner, H.: A new rock glacier inventory of the eastern European Alps, Austrian J. Earth Sci., 105, 78-93, 2012.

Kenner, R., Phillips, M., Beutel, J., Hiller, M., Limpach, P., Pointner, E., and Volken, M.: Factors controlling velocity variations at short-term, seasonal and multiyear time scales, Ritigraben rock glacier, Western Swiss Alps, Permafrost. Periglac., 28, 675-684, https://doi.org/10.1002/ppp.1953, 2017.

Kenyi, L. W. and Kaufmann, V.: Estimation of rock glacier surface deformation using SAR interferometry data, IEEE T. Geosci. Remote, 41, 1512-1515, https://doi.org/10.1109/TGRS.2003.811996, 2003.

Krainer, K. and Ribis, M.: A rock glacier inventory of the Tyrolean Alps (Austria), Austrian J. Earth Sci., 105, 32-47, 2012.

Lieb, G. K.: Permafrost und Blockgletscher in den östlichen österreichischen Alpen, Arbeiten aus dem Institut für Geographie der Karl-Franzens-Universität Graz, Band 33, 9-125, 1996.

Lilleøren, K. S. and Etzelmüller, B.: A regional inventory of rock glaciers and ice-cored moraines in Norway, Geogr. Ann. A, 93, 175-191, https://doi.org/10.1111/j.1468-0459.2011.00430.x, 2011.

Lilleøren, K. S., Etzelmüller, B., Gärtner-Roer, I., Kääb, A., Westermann, S., and Guðmundsson, Á.: The distribution, thermal characteristics and dynamics of permafrost in Tröllaskagi, north- 
ern Iceland, as inferred from the distribution of rock glaciers and ice-cored moraines, Permafrost. Periglac., 24, 322-335, https://doi.org/10.1002/ppp.1792, 2013.

Liu, L., Millar, C. I., Westfall, R. D., and Zebker, H. A.: Surface motion of active rock glaciers in the Sierra Nevada, California, USA: inventory and a case study using InSAR, The Cryosphere, 7, 1109-1119, https://doi.org/10.5194/tc-7-1109-2013, 2013.

Luckman, B. H. and Crockett, K. J.: Distribution and characteristics of rock glaciers in the southern part of Jasper National Park, Alberta, Can. J. Earth Sci., 15, 540-550, https://doi.org/10.1139/e78-060, 1978.

MacDonald, G. M. and Tingstad, A. H.: Recent and multicentennial precipitation variability and drought occurrence in the Uinta Mountains region, Utah, Arct. Antarct. Alp. Res., 39, 549-555, https://doi.org/10.1657/1523-0430(06070)[MACDONALD]2.0.CO;2, 2007.

Marcer, M., Cicoira, A., Cusicanqui, D., Bodin, X., Echelard, T., Obregon, R., and Schoeneich, P: Rock glaciers throughout the French Alps accelerated and destabilised since 1990 as air temperatures increased, Communications Earth and Environment, 2, 1-11, https://doi.org/10.1038/s43247-021-00150-6, 2021.

Minchew, B. M. and Meyer, C. R.: Dilation of subglacial sediment governs incipient surge motion in glaciers with deformable beds, Proc. R. Soc. A, 476, 20200033, https://doi.org/10.1098/rspa.2020.0033, 2020.

Moore, P. L.: Deformation of debris-ice mixtures, Rev. Geophys., 52, 435-467, https://doi.org/10.1002/2014RG000453, 2014.

Müller, J., Vieli, A., and Gärtner-Roer, I.: Rock glaciers on the run - understanding rock glacier landform evolution and recent changes from numerical flow modeling, The Cryosphere, 10, 2865-2886, https://doi.org/10.5194/tc-10-2865-2016, 2016.

Munroe, J. S.: Distribution, evidence for internal ice, and possible hydrologic significance of rock glaciers in the Uinta Mountains, Utah, USA, Quaternary Res., 90, 50-65, https://doi.org/10.1017/qua.2018.24, 2018.

Munroe, J. S. and Laabs, B. J. C.: Glacial Geologic Map of the Uinta Mountains Area, Utah and Wyoming, Utah Geological Survey Miscellaneous Publication, Utah Geological Survey, Salt Lake City, USA, 2009.

Nagler, T., Mayer, C., and Rott, H.: Feasibility of DINSAR for mapping complex motion fields of Alpine ice-and rock-glaciers, in: Proceedings of the Third International Symposium on Retrieval of Bio- and Geophysical Parameters from SAR Data for Land Applications, Sheffield, UK, 475, 377-382, 11-14 September 2001.

Necsoiu, M., Onaca, A., Wigginton, S., and Urdea, P.: Rock glacier dynamics in Southern Carpathian Mountains from high-resolution optical and multi-temporal SAR satellite imagery, Remote Sens. Environ., 177, 21-36, https://doi.org/10.1016/j.rse.2016.02.025, 2016.

Nicholson, L., Marín, J., Lopez, D., Rabatel, A., Bown, F., and Rivera, A.: Glacier inventory of the upper Huasco valley, Norte Chico, Chile: glacier characteristics, glacier change and comparison with central Chile, Ann. Glaciol., 50, 111-118, https://doi.org/10.3189/172756410790595787, 2009.

Perruchoud, E. and Delaloye, R.: Short-Term Changes in Surface Velocities on the Becs-de-Bosson Rock Glacier (Western Swiss Alps), Grazer Schriften der Geographie und Raumforschung, 43, 2007.
PRISM Climate Group: 30-Year Normals, Oregon State University [data set], available at: http://prism.oregonstate.edu (last access: 18 August 2021), 4 February 2004.

Rangecroft, S., Harrison, S., Anderson, K., Magrath, J., Castel, A. P., and Pacheco, P.: A first rock glacier inventory for the Bolivian Andes, Permafrost. Periglac., 25, 333-343, https://doi.org/10.1002/ppp.1816, 2014.

Rempel, A. W., Marshall, J. A., and Roering, J. J.: Modeling relative frost weathering rates at geomorphic scales, Earth Planet. Sc. Lett., 453, 87-95, https://doi.org/10.1016/j.eps1.2016.08.019, 2016.

Rick, B., Delaloye, R., Barboux, C., and Strozzi, T.: Detection and inventorying of slope movements in the Brooks Range, Alaska using DInSAR: a test study, in: Proceedings of the GEOQuébec 2015: 68th Canadian Geotechnical Conference and 7th Canadian Permafrost Conference, 20-23 September 2015, Quebec City, Canada, 2015.

Rignot, E., Hallet, B., and Fountain, A.: Rock glacier surface motion in Beacon Valley, Antarctica, from syntheticaperture radar interferometry, Geophys. Res. Lett., 29, 48-1-484, https://doi.org/10.1029/2001GL013494, 2002.

Roer, I., Kääb, A., and Dikau, R.: Rockglacier acceleration in the Turtmann valley (Swiss Alps): Probable controls, Norsk Geogr. Tidsskr., 59, 157-163, https://doi.org/10.1080/00291950510020655, 2005.

Rosen, P. A., Gurrola, E., Sacco, G. F., and Zebker, H.: The InSAR scientific computing environment, in: 9th European Conference on Synthetic Aperture Radar, 23-26 April, Nuremberg, Germany, 730-733, 2012.

Roudnitska, S., Charvet, R., Ribeyre, C., and Favreaux, B. L. Les Glaciers-Rocheux De Savoie: Inventaire, Cartographie Et Risques Associés - Rapport Provisoire, Chambery: Office National des Forets, Service de Restauration des Terrains en Montagne, 2016.

Schaffer, N., MacDonell, S., Réveillet, M., Yáñez, E., and Valois, R.: Rock glaciers as a water resource in a changing climate in the semiarid Chilean Andes, Reg. Environ. Change, 19, 1263 1279, https://doi.org/10.1007/s10113-018-01459-3, 2019.

Schmid, M.-O., Baral, P., Gruber, S., Shahi, S., Shrestha, T., Stumm, D., and Wester, P.: Assessment of permafrost distribution maps in the Hindu Kush Himalayan region using rock glaciers mapped in Google Earth, The Cryosphere, 9, 2089 2099, https://doi.org/10.5194/tc-9-2089-2015, 2015.

Schmidt, D. A. and Bürgmann, R.: Time-dependent land uplift and subsidence in the Santa Clara valley, California, from a large interferometric synthetic aperture radar data set, J. Geophys. Res.-Sol. Ea., 108, 2416-2428, https://doi.org/10.1029/2002JB002267, 2003.

Sears, J. W., Graff, P. J., and Holden, G. S.: Tectonic evolution of lower Proterozoic rocks, Uinta Mountains, Utah and Colorado, Geol. Soc. Am. Bull., 93, 990-997, https://doi.org/10.1130/00167606(1982)93<990:TEOLPR>2.0.CO;2, 1982.

Strozzi, T., Kääb, A., and Frauenfelder, R.: Detecting and quantifying mountain permafrost creep from in situ inventory, space-borne radar interferometry and airborne digital photogrammetry, Int. J. Remote Sens., 25, 2919-2931, https://doi.org/10.1080/0143116042000192330, 2004. 
Strozzi, T., Caduff, R., Jones, N., Barboux, C., Delaloye, R., Bodin, X., Kääb, A., Mätzler, E., and Schrott, L.: Monitoring rock glacier kinematics with satellite synthetic aperture radar. Remote Sens.-Basel, 12, 559, https://doi.org/10.3390/rs12030559, 2020.

Tingstad, A. H.: Climate variability and ecological response in the Uinta Mountains, Utah, inferred from diatoms and tree-rings, $\mathrm{PhD}$ thesis, University of California, Los Angeles, USA, 2010.

Villarroel, C., Tamburini Beliveau, G., Forte, A., Monserrat, O., and Morvillo, M.: DInSAR for a regional inventory of active rock glaciers in the dry Andes Mountains of Argentina and Chile with Sentinel-1 data, Remote Sens.-Basel, 10, 1588, https://doi.org/10.3390/rs10101588, 2018.

Vonder Mühll, D., Noetzli, J., Roer, I., Makowski, K., and Delaloye, R.: Permafrost in Switzerland 2002/2003 and 2003/2004, Glaciological Report (Permafrost) No. 4/5, 2007.
Wahrhaftig, C. and Cox, A.: Rock glaciers in the Alaska Range, Geol. Soc. Am. Bull., 70, 383-436, https://doi.org/10.1130/00167606(1959)70[383:RGITAR]2.0.CO;2, 1959.

Wang, X., Liu, L., Zhao, L., Wu, T., Li, Z., and Liu, G.: Mapping and inventorying active rock glaciers in the northern Tien Shan of China using satellite SAR interferometry, The Cryosphere, 11, 997-1014, https://doi.org/10.5194/tc-11-997-2017, 2017.

Wirz, V., Gruber, S., Purves, R. S., Beutel, J., Gärtner-Roer, I., Gubler, S., and Vieli, A.: Short-term velocity variations at three rock glaciers and their relationship with meteorological conditions, Earth Surf. Dynam., 4, 103-123, https://doi.org/10.5194/esurf-4-103-2016, 2016.

Zasadni, J. and Kłapyta, P.: From valley to marginal glaciation in alpine-type relief: Late glacial glacier advances in the Pięć Stawów Polskich/Roztoka Valley, High Tatra Mountains, Poland, Geomorphology, 253, 406-424, https://doi.org/10.1016/j.geomorph.2015.10.032, 2016. 